\author{
WHO VOTED FOR TRUMP? POPULISM AND SOCIAL CAPITAL \\ Paola Giuliano \\ Romain Wacziarg \\ Working Paper 27651 \\ http://www.nber.org/papers/w27651
}

\author{
NATIONAL BUREAU OF ECONOMIC RESEARCH \\ 1050 Massachusetts Avenue \\ Cambridge, MA 02138 \\ August 2020
}

The views expressed herein are those of the authors and do not necessarily reflect the views of the National Bureau of Economic Research.

NBER working papers are circulated for discussion and comment purposes. They have not been peer-reviewed or been subject to the review by the NBER Board of Directors that accompanies official NBER publications.

(C) 2020 by Paola Giuliano and Romain Wacziarg. All rights reserved. Short sections of text, not to exceed two paragraphs, may be quoted without explicit permission provided that full credit, including $(\odot$ notice, is given to the source. 
Who Voted for Trump? Populism and Social Capital

Paola Giuliano and Romain Wacziarg

NBER Working Paper No. 27651

August 2020

JEL No. D72,Z1

\section{$\underline{\text { ABSTRACT }}$}

We argue that low levels of social capital are conducive to the electoral success of populist movements. Using a variety of data sources for the 2016 US Presidential election at the county and individual levels, we show that social capital, measured either by the density of memberships in civic, religious and sports organizations or by generalized trust, is significantly negatively correlated with the vote share and favorability rating of Donald Trump around the time of the election.

Paola Giuliano

Anderson School of Management

UCLA

110 Westwood Plaza

C517 Entrepreneurs Hall

Los Angeles, CA 90095-1481

and IZA

and also NBER

paola.giuliano@anderson.ucla.edu

Romain Wacziarg

Anderson School of Management at UCLA

C-510 Entrepreneurs Hall

110 Westwood Plaza

Los Angeles, CA 90095-1481

and NBER

wacziarg@anderson.ucla.edu 


\section{Introduction}

Over the last decade, several industrialized societies have witnessed the rise of populist movements. In the United States, a form of populism opposed to globalization and immigration has long existed as a stable undercurrent of the political environment, but only recently did this movement succeed in winning a Presidential election. The rise of Donald Trump reflects the success of a populist political agenda related to that of far-right movements in Europe, such as the Front National in France, the United Kingdom's UKIP, the Alternative for Germany and the Sweden Democrats. What are the causes of the rise of populist movements in industrialized democracies?

We study this question in a specific context and with a specific angle: we propose to test the hypothesis that the popularity of Donald Trump in the 2016 US electoral cycle was negatively associated with the level of social capital, while carefully controlling for other possible causes of the rise of populism, as reflected in the existing literature on this subject. ${ }^{2}$ We hypothesize that a fraying social fabric, captured by a decline in the density of membership in civic and religious organizations, is partly responsible for the rise of populism.

While there is a vast literature on the causes of the rise of populist movements, much of which is qualitative (see for instance the excellent survey in Gidron and Bonikowski, 2013), there is less work with an explicitly quantitative approach to studying the causes of populism, and very little academic work relating populism to social capital. Indeed, the decline of social capital in the US has been both documented and argued upon (Putnam, 2000), but its political consequences have been subject to much less scrutiny. In addition, while various contributions have studied the relevance of social capital for various economic and institutional outcomes (see Algan and Cahuc, 2013, for a review), little is known about the relationship between social capital, ideology and voting. ${ }^{3}$

Why might social capital affect populism? Several channels could be operative. First, individuals with dense social networks and connections may find it easier to cope with the economic changes that result from globalization, technological progress, and immigration. For

\footnotetext{
${ }^{2}$ Notable references studying the determinants of Donald Trump's electoral performance are Rothwell et al. (2016) and Enke (2020)

${ }^{3}$ There are two exceptions: Satyanath et al, (2017) study the relationship between social capital and the rise of the Nazi party, finding that social capital, measured by the density of associations in 229 German towns, was positively associated with Nazi Party membership and electoral success. Boeri et al. (2018), find a negative association between voting for populists and the strength of civil society in Europe and Latin America.
} 
instance, social connections may allow the easier professional reconversion of a worker whose wage or employment status has been affected by adverse economic shocks. In contrast a worker in a location where social ties are weak may be more responsive to populist messages that blame immigrants, globalization and technology for their woes. Social capital in this sense is associated with more reciprocity and risk-sharing. Second, social ties may also affect the expression of populist views, if they are not widely shared within the social network, through normative pressure from others to avoid outside-of-the-mainstream political expression (this effect can be reversed if populist views are widely held within the network). Thirdly, in the presence of low social capital and the corresponding lack of trust in the traditional institutions of civil society, individuals with low social connections may be more likely to blame elites and seek an outsider to replace them: a populist candidate acts as a substitute for institutions and politicians in which the voter with few social connections places very low levels of trust.

We pursue the analysis on two fronts. First, we consider cross-county variation for the US in the 2016 electoral cycle, using data on vote shares for Donald Trump in the general election and the Republican primaries. The electoral data are combined with data on social capital and civic participation at the county level and data on a large set of county characteristics (education levels, median income, racial composition, the level of unemployment, etc.) to control for possible confounders that could be driving both Trump support and social capital. Second, we use individual-level survey data on Trump support and voting behavior in both the general elections and in Republican primaries. The individual-level analysis further limits the possibility that differences in voting behavior are driven by confounders such as the individual level of education, the respondent's labor market status, as well as differences in religious beliefs which could be correlated with social capital and also affect individual ideology.

\section{Data}

\subsection{County level data}

Social Capital. Our measure of social capital comes from the updated version of Rupasingha et al. (2006). The authors create a social capital index using a principal component analysis based on four variables. The first variable is given by an aggregate measure of density of various organizations including civic, religious, professional, political and sports organizations at the county level. The data were obtained from the county business pattern database compiled by the Census Bureau. The second variable is voter turnout, the third is the Census response rate, and 
the fourth is the number of non-profit organizations without including those with an international approach. ${ }^{4}$ The authors collect data for 2009 and 2014. We average the social capital index over these two years to limit the incidence of measurement error. Their data is based on Putnam's view of social capital: social capital refers to "the connection among individuals - social networks and the norms of reciprocity and trustworthiness that arise from them”. For Putnam, participation in political and social activities and collective organizations is an important facet of social capital as "individual participation in social and political organizations instills in their members habits of economic cooperation, solidarity and public spiritedness” (Putnam, 1993), 89-90). ${ }^{5}$

As an alternative measure of social capital, we also use a subjective measure of trust obtained from the General Social Survey. This measure has been extensively used as a proxy for social capital (Guiso et al., 2016). ${ }^{6}$

Trump Vote Share and county control variables. County level measures of vote share for Donald Trump in the Republican primaries and Presidential Elections were obtained from Leip (2016). Control variables at the county level include education, population density, unemployment, manufacturing employment share, income and racial composition. ${ }^{7}$

\subsection{Individual level data}

We use two different datasets at the individual level: the Cooperative Congressional Election Study (CCES) and the Gallup U.S. Daily Tracking survey.

CCES. The CCES is a 64,600 person national stratified sample survey administered by YouGov/Polimetrix. The 2016 survey consists of two waves: The first wave, collected before the election, asks about general political attitudes, and various demographic questions. The second wave, collected after the election, mostly contains information about items related to the election. The pre-election wave of the questionnaire was in the field from September $28^{\text {th }}$ to November $7^{\text {th }}$, 2016, whereas the post-election wave was in the field from November $9^{\text {th }}$ to December $14^{\text {th }}$. We

\footnotetext{
${ }^{4}$ We recomputed all our estimates using only the sub-component of the social capital index that captures the density of associations, also averaged over 2009 and 2014. The results were unchanged relative to our baseline results using the index of social capital based on the first principal component of all four variables.

${ }^{5}$ Putnam (2000) views the decline of participation in groups such the Boy and Girl Scouts; service clubs such as the Lions and League of Women Voters; and particularly Parents Teacher Associations, as a sign of America's dwindling social capital.

${ }^{6}$ The question asks "Generally speaking, would you say that most people can be trusted (taking the value of one) or that you can't be too careful in dealing with people (taking the value of zero)?". The data was pooled over all available GSS waves and then shares of respondents giving each of the two possible answers were calculated at the level of counties using county identifiers from the restricted version of the GSS.

${ }^{7}$ The sources for these control variables are https://www.kaggle.com/benhamner/2016-us-election (retrieved April 16, 2016) and the Bureau of Labor Statistics.
} 
use the variable on voting during the primaries and the question on whether the individual preferred Trump as a President from the pre-election segment, together with all the controls included in our regressions. The question on actual voting during the election is obtained from the post-election questionnaire. $^{8}$

Gallup U.S. Daily Tracking. The Gallup U.S. Daily Tracking survey microdata, collected from July $8^{\text {th }} 2015$ until the end of 2016, contains information on a sample of 146,943 American adults who were asked if they held a favorable view of Donald Trump. ${ }^{9}$

Both surveys include a large set of individual controls, including demographics (age, gender and race), education, income, marital and labor market status, whether religion is important and how often the individual goes to church. The CCES also contains information on home ownership and whether the person does not have health insurance.

\section{Empirical Analysis}

\subsection{Summary Statistics}

Descriptive statistics for all the variables of interest are provided in Tables A1 and A2 for the county level and individual level datasets, respectively (more details about data sources and variable definitions are provided in the Online Appendix). In the county-level electoral results dataset, we see that Donald Trump won $45.48 \%$ of counties in the primary, and $62.07 \%$ of the counties in the general election. Consider next the CCES dataset: of the 51,847 individuals expressing a preference for a presidential candidate, 30.3\% were favorable to Trump. The sample of individuals who reported voting in the primaries is much smaller (32,109 individuals); of these, 20.5\% voted for Donald Trump. The fraction of people who voted for Trump in the general election is equal to $40.8 \%$ (in a sample of 37,501 individuals). Finally, in the Gallup daily dataset, 36.9\% of respondents had a favorable view of Trump. ${ }^{10}$

\footnotetext{
${ }^{8}$ The precise wording of the questions in the pre-election survey are "In the Presidential primary or caucus, who did you vote for" and "Which candidate for President of the United States do you prefer". In the post-election survey, they asked "For whom did you vote for President of the United States".

${ }^{9}$ The precise wording of the question is "We would like to get your overall opinion of some people in the news". The person they then ask about is "Businessman Donald Trump". Choices are between: "favorable", "unfavorable", "I have heard of him but I have no opinion", "I have never heard of him." We drop from our analysis all individuals responding that they have heard of him but they have no opinion or that they did not have heard of him. In Table A7 we show the robustness of our results to the inclusion of these individuals in our regression sample and coded as zero.

${ }^{10}$ For the extended sample of Table A7, 35.54\% of the sample has a favorable view of Trump, $60.88 \%$ has an unfavorable view, $3.01 \%$ reported no opinion and $0.57 \%$ said they had not heard of Donald Trump. These three last categories are all coded as zero.
} 


\subsection{County-level analysis}

We start by examining whether there exists a systematic correlation at the county level between Trump vote shares in the Republican primaries and general elections, and social capital. We ask whether counties with low degrees of social capital were particularly prone to featuring high vote shares for Donald Trump.

We report partial correlation plots for vote shares in the Republican primaries and the general election in Figures 1-2. ${ }^{11}$ These were obtained from the regressions in Table 1. A number of facts are apparent from these regressions and figures. First, support for Trump in the primaries and general elections is strongly negatively correlated with social capital. Second, these correlations are robust even after including a large set of county-level controls. Third, the figures show that the relationship is not driven by a small number of counties. Finally, the size of the coefficients is also meaningful: the beta coefficient on the level of social capital for the Republican primaries is equal to $-8.8 \%$, whereas for the general elections it is equal to $-6.4 \% .^{12}$

\subsection{Individual-level Analysis}

In the second part of our analysis, we turn to OLS multivariate regression estimates of the relationship between support for Trump and the level of social capital in the county of residence, at the individual level. Using a multivariate regression framework allows us to account for a host

\footnotetext{
11 The regressions reported in Table 1 control for the level of unemployment, population density (to proxy for differences between rural and urban areas), the share of individuals with a level of education higher than high school, median income, the fraction of Whites, Blacks and Hispanics, and the change in manufacturing employment from 2000 until 2015. In addition, all the regressions include state-level fixed-effects. The controls have the expected sign: education and population density are negatively related to Trump support. Race is also an important predictor (Trump support is correlated with the share of Whites in the county, and negatively related with the fraction of Hispanic and African Americans, with this last variable significant only in the general election but not in the primaries). A higher level of unemployment and lower income both predict support for Trump in the primaries. Interestingly, the results are different for the general elections, where the unemployment rate is no longer significant and income becomes a positive predictor: high income counties are in the Republican camp for the general election, but did not support Trump in the Republican primaries. The change in manufacturing employment from 2000 until 2015 does not appear to play a role, in contrast to much discussion of the role of deindustrialization for the rise of populism.

${ }^{12}$ For comparison with other determinants of social capital: In the regression explaining the primary election vote share, the beta coefficients for the level of unemployment, population density and the share of individuals with a level of education higher than high school are respectively equal to $11.9 \%,-11.6 \%$ and $12.7 \%$. The magnitude for racial composition is also similar ( $10.4 \%$ for whites and $-12.9 \%$ for Hispanics), whereas median income appears to have a smaller effect (-4.1\%). In the regression explaining the general election vote share, the relative magnitude of the beta coefficient on social capital is lower, as compared to population density $(-28.4 \%)$, education $(-26.7 \%)$ and the fraction of Whites, African Americans and Hispanics in the county $(52.3 \%,-23.1 \%$ and $-42.2 \%$, respectively). The sign of the coefficient on median income becomes positive, with a beta coefficient of $5.1 \%$.
} 
of other factors (education, income, religiosity, etc.) that may affect individual voting behavior, and to avoid capturing a spurious correlation between unobserved factors and Trump support in the county of residence. The individual-level controls also allow us to better capture heterogeneity at the county level.

We estimate the following equation:

$$
\text { Trump Support }_{i c s}=\alpha(\text { Social Capital })_{c}+\beta X_{i}+\mu_{s}+\varepsilon_{i c t}
$$

where Trump Support ${ }_{i c s}$ is one of our four outcomes of interest: whether the individual voted for Trump in the Republican primaries or the general elections, and whether he/she preferred Trump as a president - all taken from CCES - as well as a subjective measure of Trump’s approval, obtained from the Gallup Daily Tracking survey. The unit of observation is an individual living in county $c$ and state $s ; X_{i}$ are the individual controls described above. ${ }^{13}$ Our specification also includes a full set of state dummies $\left(\mu_{s}\right)$. Standard errors are clustered the county level.

The results are reported in Table 2. The first four columns reports estimates using the measure of social capital from Rupasingha et al. (2006). The last four columns use the generalized measure of trust obtained from the General Social Survey. ${ }^{14}$ We find a consistently negative effect of social capital on various indicators of preferences for Donald Trump: Individuals living in counties with higher social capital tended to vote less for Donald Trump in both the primaries and the elections. They also indicate lower preference for him as President and tend to have a less favorable opinion of him. The coefficients are not only statistically significant, but they are also meaningful in magnitude. Based upon the estimates from column 1-3 using CCES data, the beta coefficients for the level of social capital range from $-4.1 \%$ to $-4.6 \%$, and, in column $5-7$ using generalized trust from the GSS, they range from $-2.5 \%$ to $-4.2 \%$ (the effects are a bit smaller when the dependent variable is the favorability rating of Donald Trump from the Gallup Daily Tracking poll in columns 4 and $8,-1.2 \%$ and $-3 \%$ ). These effects are also quantitatively meaningful when compared to other economic factors such as the unemployment status of the person (1.7\%), race (5\% for being white) or education (-8.5\% for people with a four-year college degree). ${ }^{15}$ Figure 3 ,

\footnotetext{
${ }^{13}$ In terms of county-level controls, we only include population density, since there is no question asking whether the respondent is living in a rural or urban areas. We did not include any other county-level controls since each of them would simply be an average of individual characteristics, which we do observe and include in the specification. The results are however robust to the inclusion of the full set of county controls, as reported in Table A8.

${ }^{14}$ The sample is smaller for the second set of regressions as the GSS contains information only on a subset of counties. ${ }^{15}$ These comparisons refer to the regressions explaining voting in the general elections. The results are broadly similar for the other dependent variables.
} 
which shows bin scatter plots based on the regressions of columns (1)-(4), confirms these relationships.

\subsection{Endogeneity}

It is unlikely that our results are driven by reverse causality, as we use a measure of social capital that precedes voting for Trump. The inclusion of a large set of observables characteristics at the county or individual level also limits the possibility that omitted variables are an important source of bias; nevertheless there could still be some unobservable characteristics that could drive both voting for Trump and the level of social capital.

To deal with this possibility, we use an instrumental variable approach. While an ideal source of exogenous variation of social capital is difficult to find, we use social capital in neighboring counties as an instrument. Social capital in neighboring counties is calculated as the average level of social capital in adjacent counties. The idea behind the instrument is that social capital in neighboring counties could influence the level of social capital of a given county, but not political preferences directly. ${ }^{16}$

The results of the instrumental variables analysis are in Table 3. Panel A reports the first stage, indicating that the level of social capital in a given county is strongly correlated with the level of social capital in the neighboring counties. Panel B reports the reduced form estimates, confirming that the level of social capital in neighboring counties is correlated with Trump support when excluding own-county social capital (however, when we include both own-county and neighboring county social capital together in the regression, only own-county social capital remains significant). Panel C contains the second stage regressions. Estimates show that, consistent with the OLS specification, there is evidence for a strong and negative effect of social capital on the propensity to vote for Trump and on having positive opinion of him as President. The magnitude of the effect is always larger than in the corresponding OLS estimates, especially when using the GSS measure of trust as the main regressor of interest. One possibility is that our IV procedure mostly corrects for measurement error, leading to IV effects that are larger than their OLS counterparts. At any rate the IV analysis suggests that the OLS results reported earlier, if anything, understate the true magnitude of the negative effect of social capital on Trump support.

\footnotetext{
${ }^{16}$ The idea underlying the instrument is based on Persson and Tabellini (2009) who, in a cross-country context, use democracy in neighboring countries as a proxy for democratic capital.
} 


\section{Conclusion}

We document a robust negative relationship between social capital and various measures of preferences for Donald Trump around the time of the 2016 Presidential election. Whether measured by vote shares in the primary and general elections at the county level, or by individuallevel measures such as candidate favorability or self-reported voting behavior, preferences for Donald Trump are inversely related to the density of civic, religious and sports associations, as well as to a commonly used measure of generalized trust. The estimates are robust to controlling for a wide range of control variables. In sum, populist movements that seek to place the responsibility for social dysfunction on outsiders - immigrants and foreigners - seem to thrive in the very places that have experienced a disintegration of social ties in recent decades.

\section{References}

Algan, Y. and P. Cahuc, 2013, “Trust, Institutions and Economic Development”, Handbook of Economic Growth.

Boeri, T., Mishra, P., Papageorgiou, C. and A. Spilimbergo, "Populism and Civic Society”, IMF WP/18/245

Enke, Benjamin, 2020, "Moral Values and Trump Voting", forthcoming, Journal of Political Economy.

Gidron, Noam and Bart Bonikowski, 2013, "Varieties of Populism: Literature Review and Research Agenda", Working Paper Series, Weatherhead Center for International Affairs, Harvard University.

Guiso, L., Sapienza, P. and L. Zingales, 2016, “Long Term Persistence”, Journal of the European Economic Association, 14(6), pp. 1401-1436.

Leip, D., “Atlas of U.S. Presidential Elections”, 2016, https://uselectionatlas.org/

Persson, T. and G. Tabellini, 2009, "Democratic Capital: The Nexus of Political and Economic Change”, American Economic Journal: Macroeconomics, 1 (2), 88-126.

Putnam, R. D., 1993, Making Democracy Work: Civic Traditions in Modern Italy, Princeton University Press, Princeton, New Jersey.

Putnam, R. D., 2000, Bowling Alone: The Collapse and Revival of American Community”, New York: Simon and Schuster. 
Rothwell, Jonathan and Pablo Diego-Rosell, 2016, "Explaining Nationalist Political Views: The Case of Donald Trump", Working Paper, Gallup.

Rupasingha, A., S. Goetz and D. Freshwater, 2006, “The production of social capital in US counties”, The Journal of Socio-Economics, 35, 83-101.

Satyanath, S., Voigtländer, N. and J. Voth, 2017, "Bowling for Fascism: Social Capital and the Rise of the Nazi Party”, Journal of Political Economy, 125(2), 478-526. 


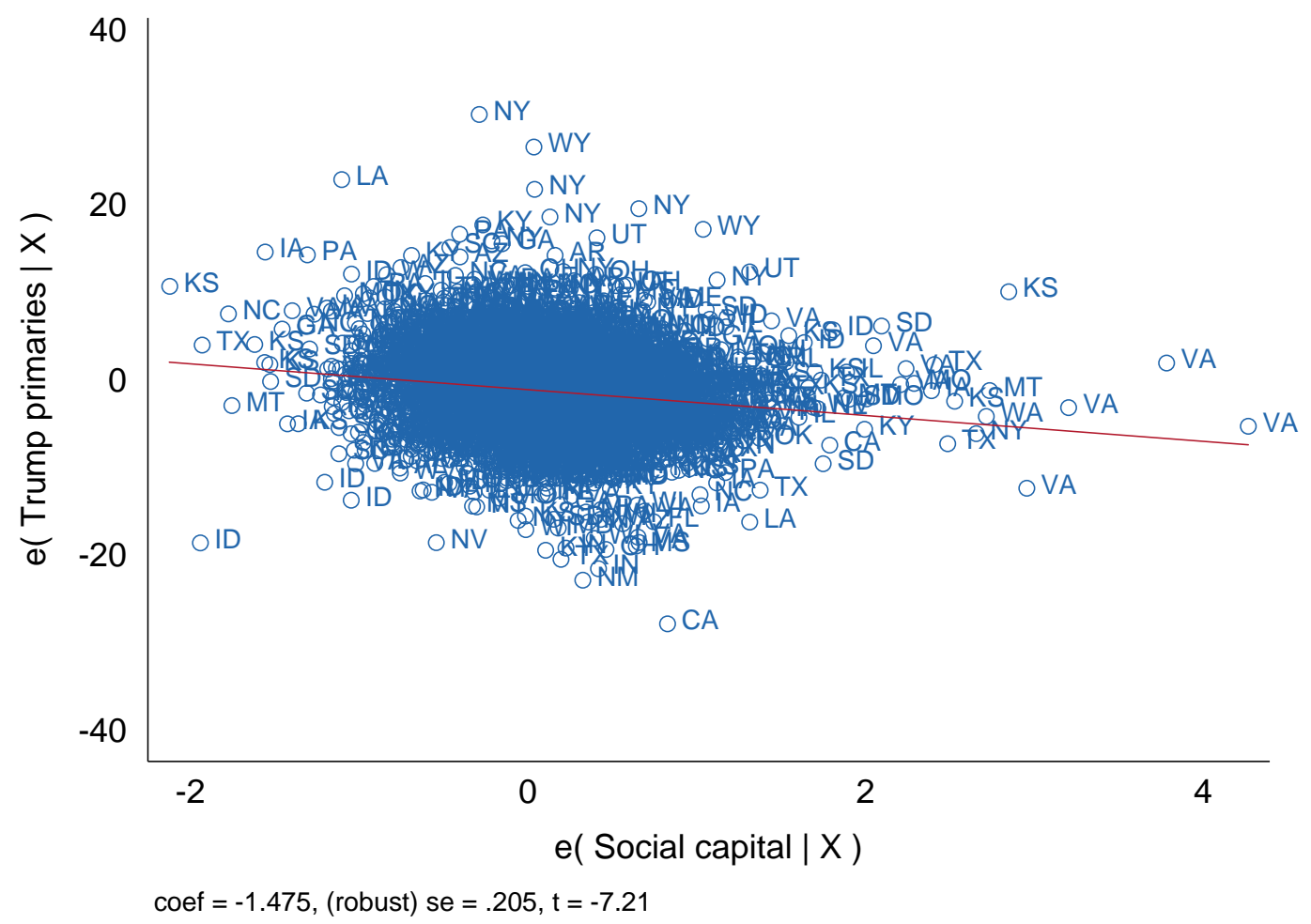

Fig. 1. Partial correlation plot: Voting for Trump in the primaries and social capital. The sample includes 2,453 counties. The specification includes state fixed-effects and county covariates [log (pop. density), fraction of Whites, African Americans and Hispanics in the county, median income, the fraction of people with a high school education or more, the unemployment rate and the change in employment in manufacturing from 2000 until 2015]. We include state labels. 


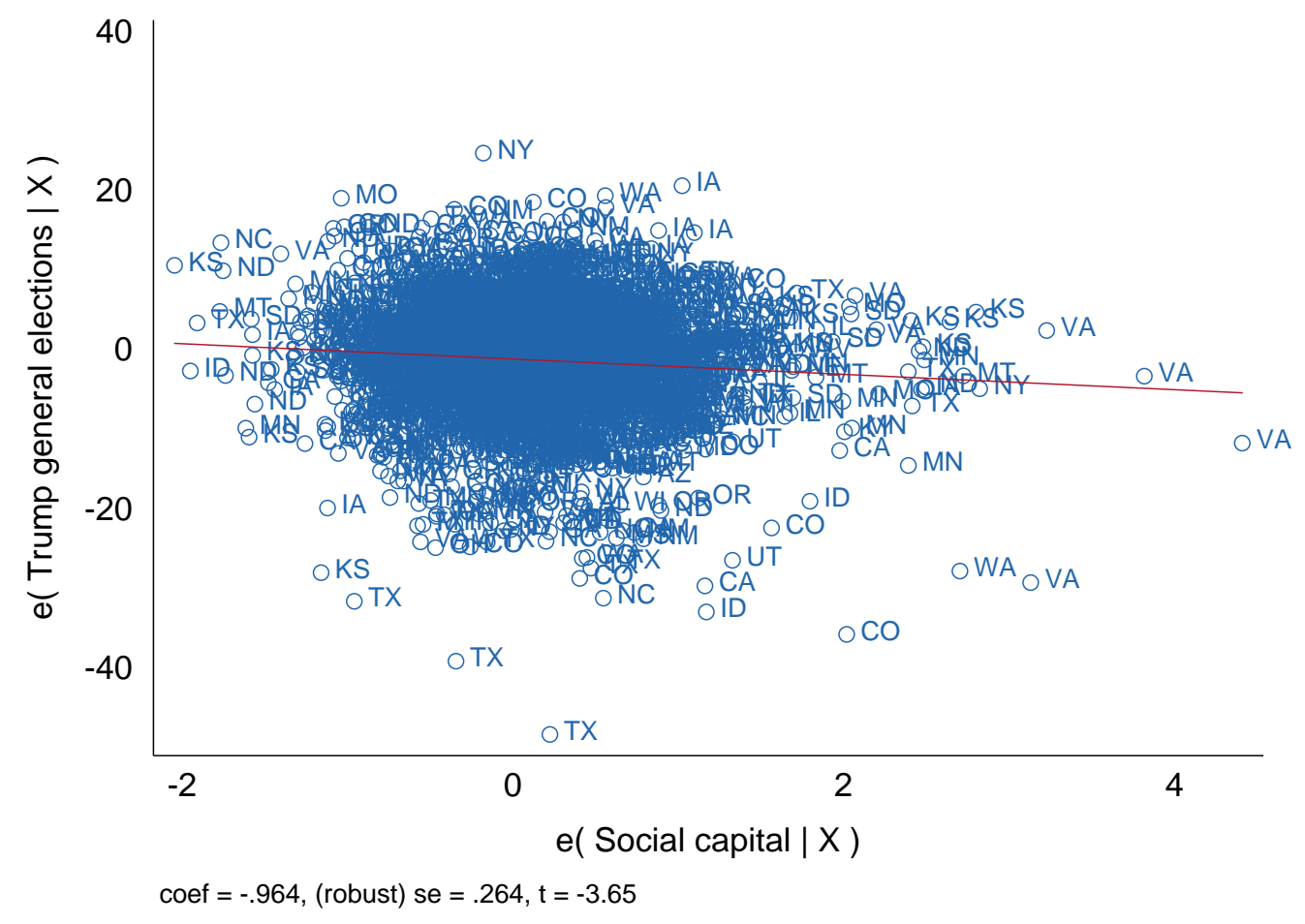

Fig. 2. Partial correlation plot: Voting for Trump in the general elections and social capital. The sample includes 2,618 counties. The specification includes state fixed-effects and county covariates [log (pop. density), fraction of Whites, African Americans and Hispanics in the county, median income, the fraction of people with a high school education or more, the unemployment rate and the change in employment in manufacturing from 2000 until 2015]. We include state labels. 

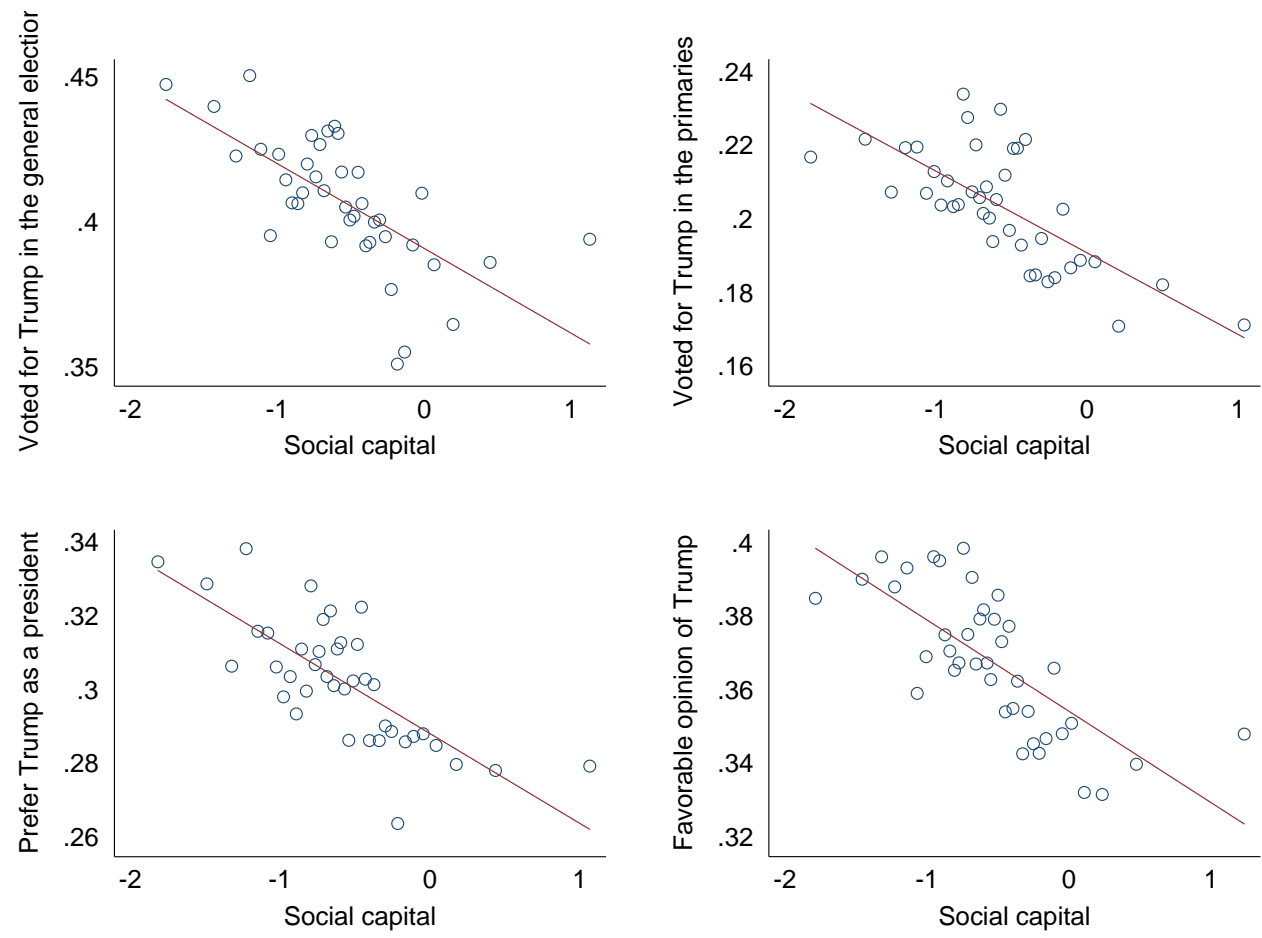

Fig. 3. Binned scatter-plots of different measures of preferences for Trump. The Figure represents binned scatter-plots of the mean of voting for Trump in the general elections and primaries, preference for Trump as a president and having a favorable opinion of Trump, graphed against the mean level of social capital. Estimates are obtained from the individual-level datasets (CCES and Gallup). Both social capital and the dependent variables are partialled out from the full set of controls included in the regressions of columns (1)-(4) of Table 2. To construct this figure, we divided the horizontal axis into 40 equal-sized (percentile) bins and plotted the four measures of political preferences averaged within bins, against the mean level of social capital in each bin. 
Table 1 - County Level Analysis

\begin{tabular}{|c|c|c|c|c|}
\hline VARIABLES & $\begin{array}{c}(1) \\
\text { Voted Trump } \\
\text { in the } \\
\text { primaries }\end{array}$ & $\begin{array}{c}(2) \\
\text { Voted Trump } \\
\text { in general } \\
\text { election }\end{array}$ & $\begin{array}{c}\text { (3) } \\
\text { Voted Trump } \\
\text { in the } \\
\text { primaries }\end{array}$ & $\begin{array}{c}(4) \\
\text { Voted Trump } \\
\text { in general } \\
\text { election }\end{array}$ \\
\hline Social capital & $\begin{array}{c}-1.475 * * * \\
(0.205)\end{array}$ & $\begin{array}{c}-0.964 * * * \\
(0.264)\end{array}$ & & \\
\hline Generalized trust (GSS) & & & $\begin{array}{l}-3.809 \\
(2.747)\end{array}$ & $\begin{array}{c}-8.489 * * * \\
(2.887)\end{array}$ \\
\hline Log (pop. density) & $\begin{array}{c}-1.239 * * * \\
(0.139)\end{array}$ & $\begin{array}{c}-2.888^{* * *} \\
(0.181)\end{array}$ & $\begin{array}{c}0.397 \\
(0.486)\end{array}$ & $\begin{array}{c}-1.633^{* * *} \\
(0.483)\end{array}$ \\
\hline Whites & $\begin{array}{c}0.105^{* *} \\
(0.041)\end{array}$ & $\begin{array}{c}0.518^{* * *} \\
(0.035)\end{array}$ & $\begin{array}{c}0.254 * * * \\
(0.087)\end{array}$ & $\begin{array}{c}0.812 * * * \\
(0.153)\end{array}$ \\
\hline African Americans & $\begin{array}{l}0.075^{*} \\
(0.043)\end{array}$ & $\begin{array}{c}-0.238^{* * *} \\
(0.039)\end{array}$ & $\begin{array}{c}0.063 \\
(0.103)\end{array}$ & $\begin{array}{l}-0.030 \\
(0.171)\end{array}$ \\
\hline Hispanics & $\begin{array}{c}-0.165^{* * *} \\
(0.021)\end{array}$ & $\begin{array}{c}-0.522^{* * *} \\
(0.037)\end{array}$ & $\begin{array}{c}-0.210^{* * *} \\
(0.072)\end{array}$ & $\begin{array}{c}-0.495^{* * *} \\
(0.080)\end{array}$ \\
\hline High School or Higher & $\begin{array}{c}-0.303^{* * *} \\
(0.048)\end{array}$ & $\begin{array}{c}-0.611^{* * *} \\
(0.055)\end{array}$ & $\begin{array}{c}-0.607 * * * \\
(0.141)\end{array}$ & $\begin{array}{c}-0.827 * * * \\
(0.150)\end{array}$ \\
\hline Median Income & $\begin{array}{c}-0.550^{* *} \\
(0.218)\end{array}$ & $\begin{array}{c}0.650^{* *} \\
(0.269)\end{array}$ & $\begin{array}{c}1.114^{* *} \\
(0.517)\end{array}$ & $\begin{array}{c}1.280^{* *} \\
(0.552)\end{array}$ \\
\hline Unemployment rate & $\begin{array}{c}1.145^{* * *} \\
(0.205)\end{array}$ & $\begin{array}{l}-0.097 \\
(0.159)\end{array}$ & $\begin{array}{c}3.083 * * * \\
(0.640)\end{array}$ & $\begin{array}{c}1.911 * * * \\
(0.654)\end{array}$ \\
\hline $\begin{array}{l}\text { Change in manufacturing (2000- } \\
\text { 2015) }\end{array}$ & $\begin{array}{c}0.087 \\
(0.248)\end{array}$ & $\begin{array}{c}0.332 \\
(0.388)\end{array}$ & $\begin{array}{c}0.205 \\
(1.678)\end{array}$ & $\begin{array}{c}5.646^{* * *} \\
(1.802)\end{array}$ \\
\hline State fixed-effects & yes & yes & yes & yes \\
\hline Mean (st. dev.) of dep. variable & $45.48(15.57)$ & $62.07(15.01)$ & $46.31(16.62)$ & $48.39(17.15)$ \\
\hline Observations & 2,453 & 2,618 & 315 & 329 \\
\hline R-squared & 0.88 & 0.795 & 0.901 & 0.886 \\
\hline Standardized beta on Social Capital & -0.088 & -0.064 & -0.04 & -0.085 \\
\hline
\end{tabular}

Notes: The unit of observation is a county. Coefficients are clustered at the state level. The measure of social capital comes from the updated version of Ruphasinga et al. (2006). Details are provided in the Online Appendix. Generalized trust (GSS) is the fraction of people in a county during the 1972-2010 period answering 1 to the following question: "Generally speaking, would you say most people can be trusted (taking the value of 1) or that you can't be too careful in dealing with people (taking the value of zero)". The dependent variables are vote shares for Donald Trump in the Republican Primaries and Presidential Elections and taken from Leip's Atlas of Presidential Elections (2016). Details about the control variables are provided in the Online Appendix. ***, **, and $*$ indicate significance at the $1 \%, 5 \%$, and $10 \%$ levels. 


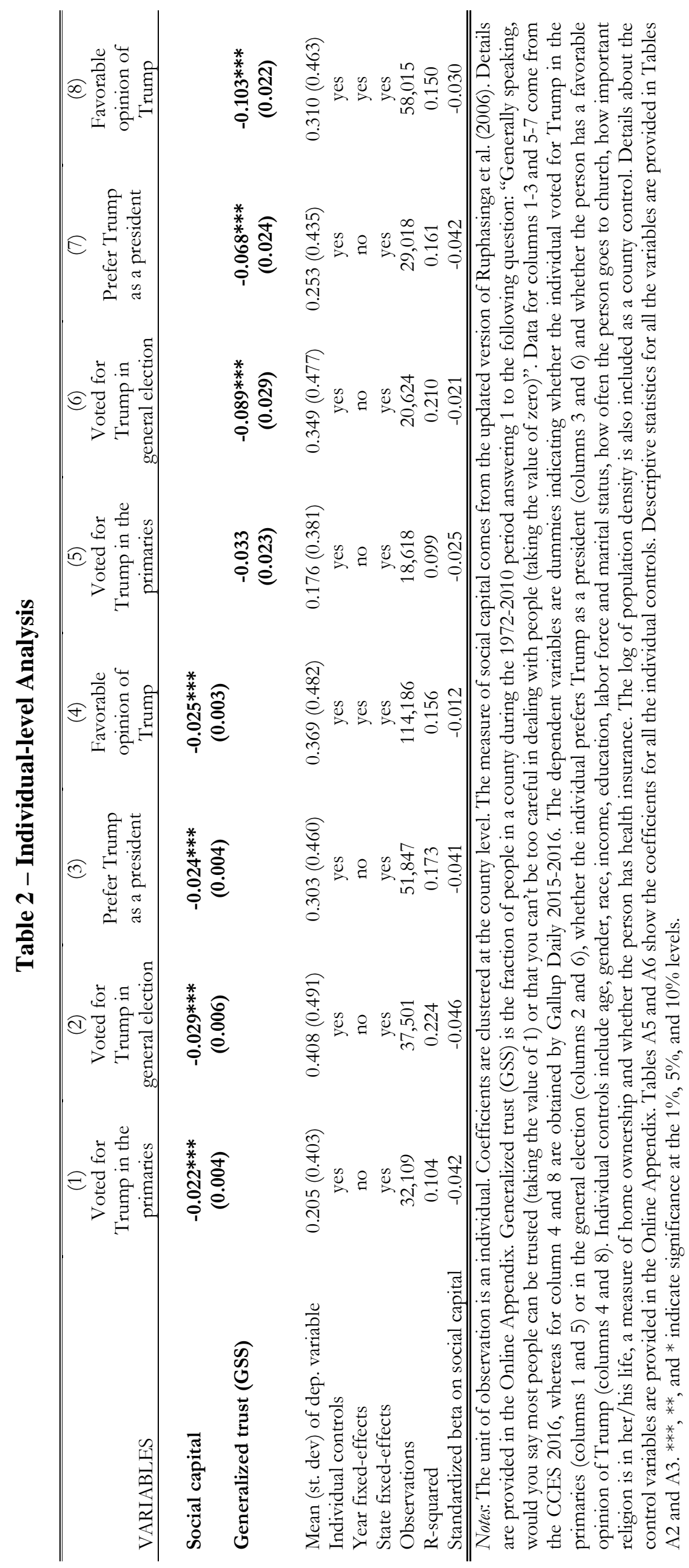




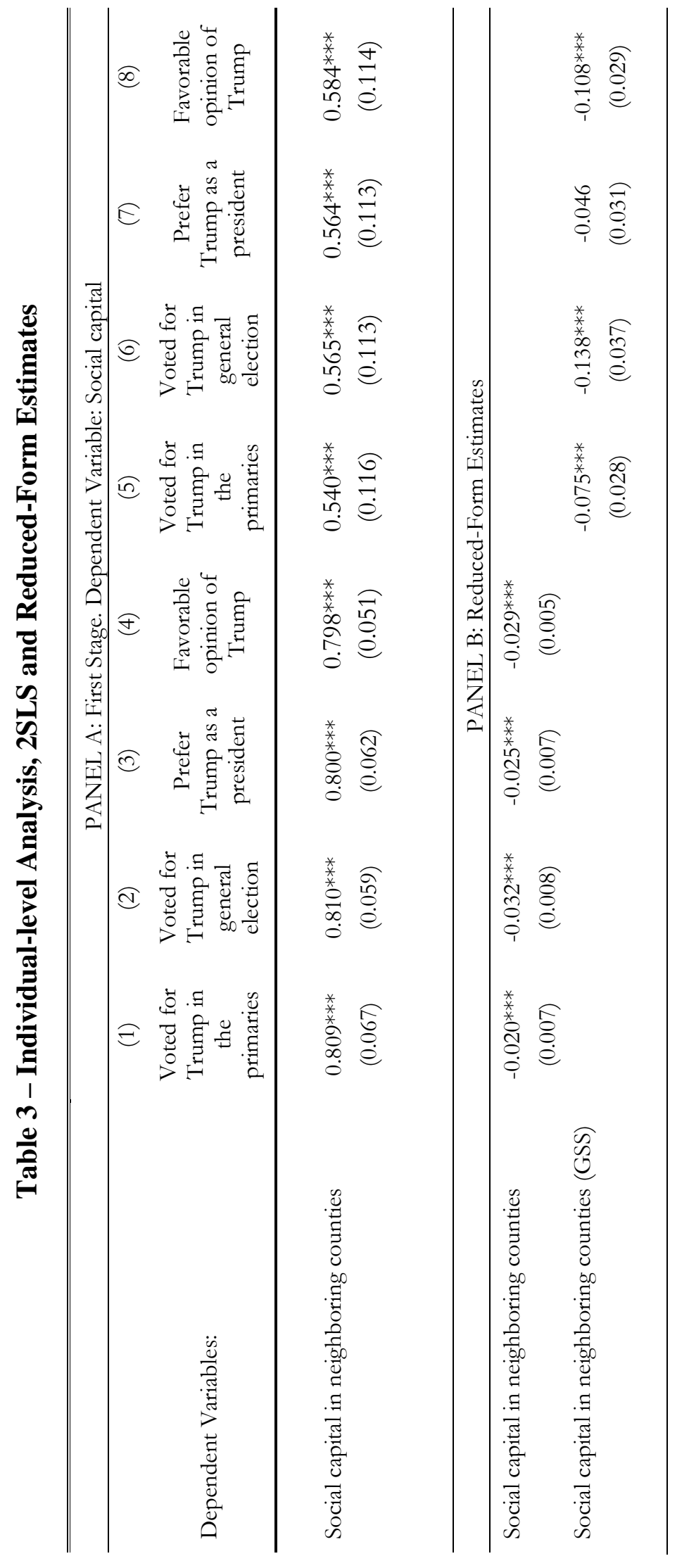




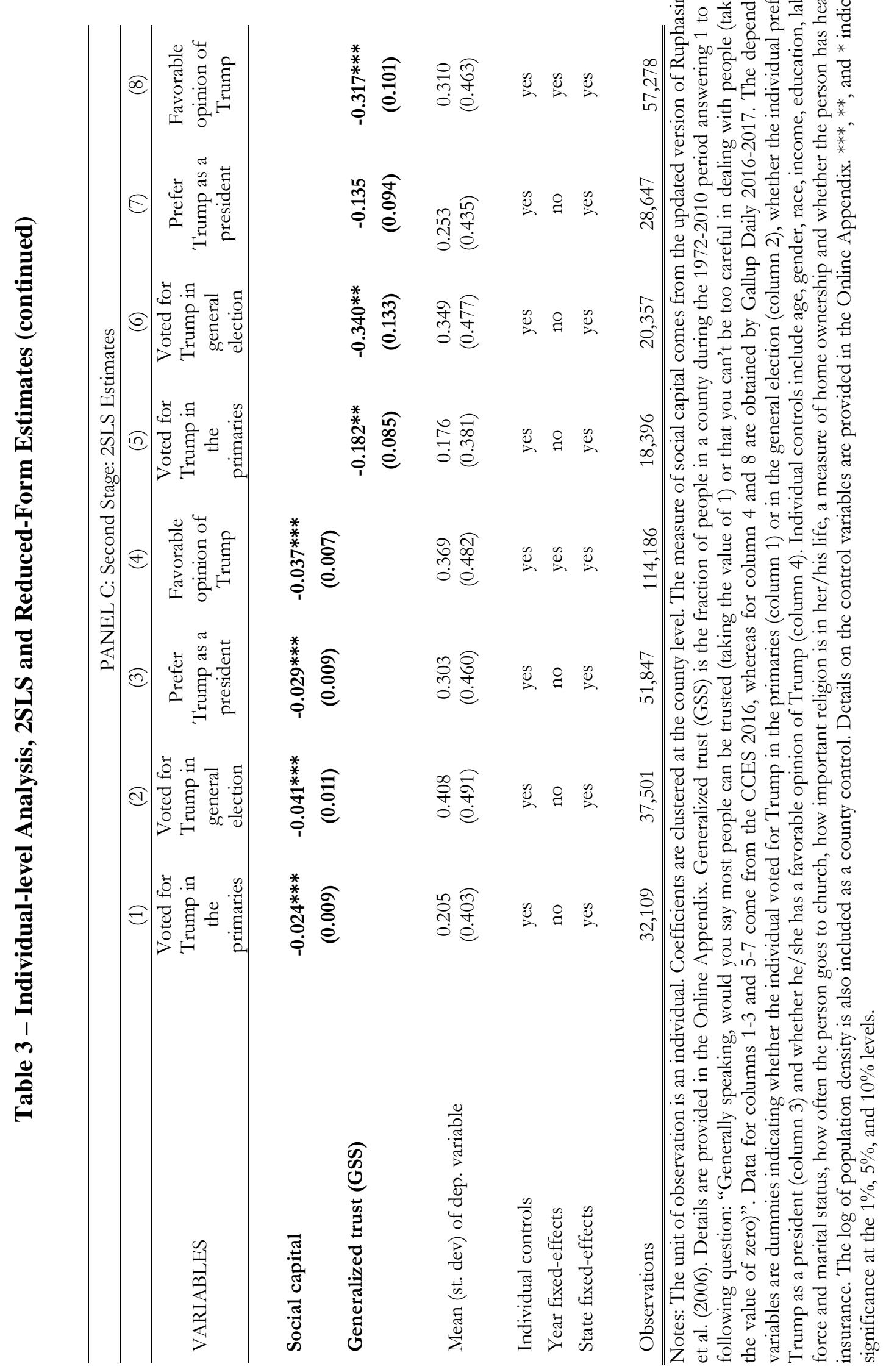




\title{
Online Appendix for \\ Who Voted for Trump? Populism and Social Capital
}

\author{
Paola Giuliano ${ }^{1,2}$, Romain Wacziarg ${ }^{1,2} *$
}

July 2020

${ }^{1}$ UCLA Anderson School of Management

${ }^{2} \mathrm{NBER}$

*Corresponding author: wacziarg@ucla.edu 


\section{Overview}

This set of supplementary materials provides details on the data used in the paper (Section A) as well as an analysis of the robustness of its empirical results (Section B).

\section{A. Data}

\section{Measures of social capital}

We use two measures of social capital. The first one is the social capital measure assembled by Rupasingha, Goetz and Freshwater (2006), who collected detailed information on the density of civic, religious and sports organizations at the county level. We use the updated measure from Rupasingha, Goetz and Freshwater (2006), referring to 2009 and 2014, and average the measure of social capital over these two years. The measure of association density is obtained from the county business pattern database compiled by the Census Bureau, which contains detailed information about membership in the following organizations:

- Number of establishments in religious organizations

- Number of establishments in civic and social associations

- Number of establishments in business associations

- Number of establishments in political organizations

- Number of establishments in professional organizations

- Number of establishments in labor organizations

- Number of establishments in bowling centers

- Number of establishments in fitness and recreational sports centers

- Number of establishments in golf courses and country clubs

- Number of establishments in sports teams and clubs

The Social Capital index is created using principal component analysis based on four factors. The $1^{\text {st }}$ factor is given by the aggregate measure of all of above variables divided by population per 1,000 . The second factor is given by voter turnout, the third factor by the Census response rate and finally the fourth factor is given by the number of non-profit organizations without including those with an international approach. The four factors are standardized to have a mean of zero and a standard deviation of one, and the first principal component is the index of social capital.

The second measure of social capital is obtained from the General Social Survey (GSS), a survey conducted by the University of Chicago's National Opinion Research Center (NORC). Adults (18 and over) are questioned in face-to-face interviews. The GSS is a repeated cross-section containing information about demographic variables, behaviors and attitudes on a variety of issues, including government spending, race relations, and religion. The survey was conducted every year between 1972 and 1994 (with the exception of 1979, 1981 and 1992). Since 1994, the survey has been conducted every other year instead of annually. To calculate the measure of social capital, we use the answer to the following question: "Generally speaking, would you say that most people can be trusted (taking the value of one) or that you can't be too careful in dealing with people (taking the 
value of zero)?”. We pool the data over all available GSS waves and calculate the share of respondent answering one to the above question at the county level, using county identifiers from the restricted version of the GSS.

\section{County-level data}

County level measures of vote share for Donald Trump in the Republican primaries and Presidential Elections are obtained from Leip (2016).

The following county-level controls are obtained from the census: population per square mile (2010), percentage of the population aged 25 and above with high school education or more (20092013), median household income (2009-2013), the percentage of Whites, African Americans and Hispanics (2014). The measures of unemployment (2016) and the change in manufacturing employment for the 2000-2015 period are obtained from the Bureau of Labor Statistics.

\section{Individual-level data}

We use two different datasets for the individual-level analysis: the Cooperative Congressional Election Study (CCES) and the Gallup U.S. Daily Tracking poll.

The CCES is a 64,600 person national stratified sample survey administered by YouGov/Polimetrix. The survey consists of two waves in election years. In the pre-election phase, respondents answer two-thirds of the questionnaire. The first segment asks about general political attitudes, and various demographic questions. The second segment, collected during the postelection phase, mostly collect information about items related to the election. The pre-election wave of the questionnaire was in the field from September $28^{\text {th }}$ to November $7^{\text {th }}$, 2016, whereas the post-election wave was in the field from November $9^{\text {th }}$ to December $14^{\text {th }}$.

The Gallup U.S. Daily Tracking survey microdata is made up of two surveys: the Gallup U.S. Daily political and economic survey and the Gallup-Healthways Well-Being Index. For both surveys, Gallup conducts 500 interviews across the U.S. per day, 350 days out of the year, $70 \%$ of them to cellphones and $30 \%$ to landlines. We use data from the political and economic survey, collected from July $8^{\text {th }} 2015$ until the end of 2016, and which contains information on a sample of 146,943 American adults.

\section{a. Questions on political preferences}

We use three questions from the CCES. Two questions are taken from the pre-election survey: "In the Presidential primary or caucus, who did you vote for?" and "Which candidate for President of the United States do you prefer?”. We use the following question from the post-election survey: "For whom did you vote for President of the United States?”.

We use the following questions from the Gallup U.S. Daily Tracking "We would like to get your overall opinion of some people in the news". The person they then ask about is "Businessman Donald Trump". Choices are between: "favorable", "unfavorable", "I have heard of him but I have no opinion", "I have never heard of him." In the specification reported in Table 2. we drop from our analysis all individuals responding that they have heard of him but they have no opinion or that they did not have heard of him. In Table S7 we show the robustness of our results to the inclusion of these individuals in our regression sample, when recoded as zero. 


\section{b. Individual controls}

Individual controls included in the CCES specification are age, gender, race (dummies for Whites, African Americans and Hispanics; the excluded group is given by individuals of any other race), education (dummies for high school, some college, two years of college, four years of college and post-graduate; the excluded group if given by individuals who dropped out of high school), marital status (dummies if the person is married, divorced or separated, or widowed; the excluded group are singles), labor market status (dummies for unemployed and out of the labor force; the excluded group are individuals who are employed), income dummies (family income between $\$ 10,000$ $\$ 19,999$, \$20,000-\$29,999, \$30,000-\$39,999, \$40,000-\$49,999, \$50,000-\$59,999, \$60,000\$69,999, \$70,000-\$79,999, \$80,000-\$99,999; \$100,000-\$119,999; \$120,000-\$149,999; \$150,000$\$ 199,999$, \$200,000-\$249,999, \$250,000-\$349,999, \$350,000-\$499,999, \$500,000 or more; the excluded group is given by individuals with family income lower than $\$ 10,000$ ); church attendance (dummies if the person goes seldom, a few times a year, once or twice a month, once a week, more than twice a week; the excluded group is given by individuals who never go to church); importance of religion (dummies indicating if religion is not too important, somewhat important or very important; the excluded group is given by individuals for which religion is not important at all), home ownership (a dummy indicating whether the person is renting a home, with the excluded group given by people who own it) and lack of health insurance (a dummy indicating if individuals do not have any health insurance).

Individual controls included in the Gallup Daily specification are age, gender, race (dummies for Whites, African Americans and Hispanics; the excluded group is given by individuals of any other race), education (dummies for high school, technical or vocational school, some college, college graduate and post-graduate; the excluded group if given by individuals who dropped out of high school), marital status (dummies if the person is married, divorced or separated, or widowed; the excluded group are singles), labor market status (dummies for unemployed and out of the labor force; the excluded group are individuals who are employed), income dummies (family income between \$720-\$5,999, \$6,000-\$11,999, \$12,000-\$23,999, \$24,000-\$35,999, \$36,000-\$47,999, $\$ 48,000-\$ 59,999, \$ 60,000-\$ 89,999, \$ 90,000-\$ 119,999 ; \$ 120,000$ and over; the excluded group is given by individuals with family income lower than $\$ 720$ ); church attendance (dummies if the person goes seldom, about once a month, almost every week and every week; the excluded group is given by individuals who never go to church); importance of religion (a dummy indicating if religion is important to the person; the excluded group is given by individuals for which religion is not important). 


\section{B. Additional Empirical Results}

Table A1. Descriptive Statistics, County-level Analysis

\begin{tabular}{lccc}
\hline & Obs. & Mean & St. dev. \\
\hline \multicolumn{4}{c}{ Sample for social capital regressions } \\
\hline Social capital & 2,453 & -0.232 & 0.927 \\
Voted Trump in the primaries & 2,453 & 45.484 & 15.568 \\
Voted Trump in general elections & 2,618 & 62.069 & 15.009 \\
Log (pop. Density) & 2,453 & 4.221 & 1.458 \\
Whites & 2,453 & 84.684 & 15.427 \\
African Americans & 2,453 & 10.409 & 14.836 \\
Hispanics & 2,453 & 8.326 & 12.180 \\
High School or Higher & 2,453 & 84.298 & 6.550 \\
Median income & 2,453 & 4.577 & 1.173 \\
Unemployment rate & 2,453 & 4.964 & 1.612 \\
Change manufacturing (2000-2015) & 2,453 & -0.222 & 0.437 \\
\hline \multicolumn{4}{c}{ Sample for Generalized trust } \\
\hline Generalized trust GSS & 315 & 0.372 & \\
Voted Trump in the primaries & 315 & 46.309 & 16.620 \\
Voted Trump in general elections & 329 & 48.386 & 17.154 \\
Log (pop. Density) & 315 & 6.012 & 1.540 \\
White & 315 & 78.384 & 15.729 \\
African Americans & 315 & 13.914 & 14.532 \\
Hispanics & 315 & 12.458 & 13.268 \\
High School or Higher & 315 & 86.826 & 5.210 \\
Median income & 315 & 5.613 & 1.541 \\
Unemployment rate & 315 & 4.650 & 1.122 \\
Change manufacturing (2000-2015) & 315 & -0.248 & 0.276 \\
\hline \hline
\end{tabular}


Table A2. Descriptive Statistics, CCES, Individual-level Analysis

\begin{tabular}{|c|c|c|c|c|c|c|c|}
\hline & Obs. & Mean & St. dev. & & Obs. & Mean & St. dev. \\
\hline Voted Trump primaries & 32,109 & 0.205 & 0.403 & Female & 32,109 & 0.499 & 0.500 \\
\hline Voted Trump general elections & 37,501 & 0.408 & 0.491 & High School & 32,109 & 0.206 & 0.404 \\
\hline Prefer Trump & 51,847 & 0.303 & 0.460 & Some college & 32,109 & 0.236 & 0.425 \\
\hline Social capital & 32,109 & -0.577 & 0.755 & Two year college & 32,109 & 0.118 & 0.322 \\
\hline Log (pop density) & 32,109 & 6.395 & 1.670 & Four year college & 32,109 & 0.266 & 0.442 \\
\hline Age & 32,109 & 49.857 & 16.402 & Post-graduate & 32,109 & 0.160 & 0.366 \\
\hline Family income $\$ 10,000-\$ 19,999$ & 32,109 & 0.057 & 0.232 & White & 32,109 & 0.736 & 0.441 \\
\hline Family income $\$ 20,000-\$ 29,999$ & 32,109 & 0.093 & 0.290 & African american & 32,109 & 0.126 & 0.332 \\
\hline Family income $\$ 30,000-\$ 39,999$ & 32,109 & 0.104 & 0.305 & Hispanic & 32,109 & 0.072 & 0.258 \\
\hline Family income $\$ 40,000-\$ 49,999$ & 32,109 & 0.098 & 0.297 & Married & 32,109 & 0.631 & 0.483 \\
\hline Family income $\$ 50,000-\$ 59,999$ & 32,109 & 0.103 & 0.304 & Divorce/separated & 32,109 & 0.114 & 0.318 \\
\hline Family income $\$ 60,000-\$ 69,999$ & 32,109 & 0.083 & 0.276 & Widowed & 32,109 & 0.046 & 0.209 \\
\hline Family income $\$ 70,000-\$ 79,999$ & 32,109 & 0.092 & 0.289 & Renting a home & 32,109 & 0.280 & 0.449 \\
\hline Family income $\$ 80,000-\$ 99,999$ & 32,109 & 0.112 & 0.315 & No health insurance & 32,109 & 0.053 & 0.224 \\
\hline Family income $\$ 100,000-\$ 119,999$ & 32,109 & 0.082 & 0.274 & Church: seldom & 32,109 & 0.210 & 0.407 \\
\hline Family income $\$ 120,000-\$ 149,999$ & 32,109 & 0.075 & 0.263 & Church: a few times a year & 32,109 & 0.142 & 0.349 \\
\hline Family income $\$ 150,000-\$ 199,999$ & 32,109 & 0.039 & 0.193 & Church: once or twice a month & 32,109 & 0.091 & 0.287 \\
\hline Family income $\$ 200,000-\$ 249,999$ & 32,109 & 0.018 & 0.132 & Church: once a week & 32,109 & 0.208 & 0.406 \\
\hline Family income $\$ 250,000-\$ 349,999$ & 32,109 & 0.009 & 0.097 & Church: more than twice a week & 32,109 & 0.090 & 0.286 \\
\hline Family income $\$ 350,000-\$ 499,999$ & 32,109 & 0.004 & 0.061 & Religion: not too important & 32,109 & 0.143 & 0.351 \\
\hline Family income $\$ 500,000$ or more & 32,109 & 0.004 & 0.062 & Religion: somewhat important & 32,109 & 0.258 & 0.437 \\
\hline Unemployed & 32,109 & 0.041 & 0.199 & Religion: very important & 32,109 & 0.392 & 0.488 \\
\hline Out of labor force & 32,109 & 0.366 & 0.482 & & & & \\
\hline
\end{tabular}


Table A3. Descriptive statistics, Gallup U.S. Daily Tracking, Individual-level Analysis

\begin{tabular}{lccclccc}
\hline & Obs. & Mean & St. dev. & Obs. & Mean & St. dev. \\
\hline Favourable opinion of Trump & 114,186 & 0.369 & 0.482 & Widowed & 114,186 & 0.086 & 0.280 \\
Social capital & 114,186 & -0.545 & 0.809 & Income: $\$ 720-\$ 5,999$ & 114,186 & 0.013 & 0.115 \\
Generalized trust & 58,015 & 0.372 & 0.136 & Income: $\$ 6,000-\$ 11,999$ & 114,186 & 0.028 & 0.166 \\
Female & 114,186 & 0.475 & 0.499 & Income: $\$ 12,000-\$ 23,999$ & 114,186 & 0.091 & 0.287 \\
High School & 114,186 & 0.217 & 0.412 & Income: $\$ 24,000-\$ 35,999$ & 114,186 & 0.118 & 0.323 \\
Technical/vocational school & 114,186 & 0.036 & 0.185 & Income: $\$ 36,000-\$ 47,999$ & 114,186 & 0.091 & 0.287 \\
Some College & 114,186 & 0.257 & 0.437 & Income: $\$ 48,000-\$ 59,999$ & 114,186 & 0.100 & 0.300 \\
College graduate & 114,186 & 0.246 & 0.431 & Income: $\$ 60,000-\$ 89,999$ & 114,186 & 0.196 & 0.397 \\
Post graduate & 114,186 & 0.204 & 0.403 & Income: $\$ 90,000-\$ 119,999$ & 114,186 & 0.123 & 0.329 \\
Unemployed & 114,186 & 0.026 & 0.160 & Income: $\$ 120,000$ and over & 114,186 & 0.228 & 0.419 \\
Out of the labor force & 114,186 & 0.344 & 0.475 & Church: seldom & 114,186 & 0.255 & 0.436 \\
White & 114,186 & 0.776 & 0.417 & Church: about once a month & 114,186 & 0.114 & 0.318 \\
African American & 114,186 & 0.090 & 0.287 & Church: almost every week & 114,186 & 0.106 & 0.308 \\
Hispanic & 114,186 & 0.094 & 0.292 & Church: every week & 114,186 & 0.303 & 0.459 \\
Married & 114,186 & 0.566 & 0.496 & Religion important & 114,186 & 0.637 & 0.481 \\
Divorced/separated & 114,186 & 0.106 & 0.307 & & & \\
\hline \hline
\end{tabular}




\section{Table A4 - County-level Analysis, robustness to the restricted sample with the GSS measure of trust non-missing}

\begin{tabular}{|c|c|c|c|c|}
\hline VARIABLES & $\begin{array}{c}\text { (1) } \\
\text { Voted } \\
\text { Trump in } \\
\text { the } \\
\text { primaries }\end{array}$ & $\begin{array}{c}(2) \\
\text { Voted } \\
\text { Trump in } \\
\text { general } \\
\text { elections }\end{array}$ & $\begin{array}{c}(3) \\
\text { Voted } \\
\text { Trump in } \\
\text { the } \\
\text { primaries }\end{array}$ & $\begin{array}{c}\text { (4) } \\
\text { Voted } \\
\text { Trump in } \\
\text { general } \\
\text { elections }\end{array}$ \\
\hline Social capital & $\begin{array}{c}-5.903 * * * \\
(0.861)\end{array}$ & $\begin{array}{c}-5.245^{* * *} \\
(1.171)\end{array}$ & & \\
\hline Generalized trust (GSS) & & & $\begin{array}{l}-3.809 \\
(2.747)\end{array}$ & $\begin{array}{c}-8.489 * * * \\
(2.887)\end{array}$ \\
\hline Log (pop. density) & $\begin{array}{l}-0.409 \\
(0.398)\end{array}$ & $\begin{array}{c}-2.055^{* * *} \\
(0.472)\end{array}$ & $\begin{array}{c}0.397 \\
(0.486)\end{array}$ & $\begin{array}{c}-1.633^{* * *} \\
(0.483)\end{array}$ \\
\hline Whites & $\begin{array}{c}0.270^{* * *} \\
(0.072)\end{array}$ & $\begin{array}{c}0.831^{* * *} \\
(0.137)\end{array}$ & $\begin{array}{c}0.254 * * * \\
(0.087)\end{array}$ & $\begin{array}{c}0.812^{* * *} \\
(0.153)\end{array}$ \\
\hline African Americans & $\begin{array}{c}0.176^{* *} \\
(0.083)\end{array}$ & $\begin{array}{c}0.058 \\
(0.150)\end{array}$ & $\begin{array}{c}0.063 \\
(0.103)\end{array}$ & $\begin{array}{l}-0.030 \\
(0.171)\end{array}$ \\
\hline Hispanics & $\begin{array}{c}-0.218^{* * *} \\
(0.043)\end{array}$ & $\begin{array}{c}-0.568^{* * *} \\
(0.085)\end{array}$ & $\begin{array}{c}-0.210^{* * *} \\
(0.072)\end{array}$ & $\begin{array}{c}-0.495^{* * *} \\
(0.080)\end{array}$ \\
\hline High School of Higher & $\begin{array}{c}-0.419 * * * \\
(0.128)\end{array}$ & $\begin{array}{c}-0.736^{* * *} \\
(0.152)\end{array}$ & $\begin{array}{c}-0.607 * * * \\
(0.141)\end{array}$ & $\begin{array}{c}-0.827^{* * *} \\
(0.150)\end{array}$ \\
\hline Median Income & $\begin{array}{c}0.969 * * \\
(0.455)\end{array}$ & $\begin{array}{l}1.140^{* *} \\
(0.557)\end{array}$ & $\begin{array}{c}1.114 * * \\
(0.517)\end{array}$ & $\begin{array}{l}1.280 * * \\
(0.552)\end{array}$ \\
\hline Unemployment rate & $\begin{array}{c}2.504 * * * \\
(0.573)\end{array}$ & $\begin{array}{c}1.651^{* * *} \\
(0.608)\end{array}$ & $\begin{array}{c}3.083 * * * \\
(0.640)\end{array}$ & $\begin{array}{c}1.911^{* * *} \\
(0.654)\end{array}$ \\
\hline Change in manufacturing (2000-2015) & $\begin{array}{c}-2.417^{*} \\
(1.445)\end{array}$ & $\begin{array}{c}3.493 * * \\
(1.672)\end{array}$ & $\begin{array}{c}0.205 \\
(1.678)\end{array}$ & $\begin{array}{c}5.646^{* * *} \\
(1.802)\end{array}$ \\
\hline Observations & 313 & 327 & 315 & 329 \\
\hline R-squared & 0.922 & 0.893 & 0.901 & 0.886 \\
\hline Standardized beta on Social Capital & -0.24 & -0.207 & -0.04 & -0.085 \\
\hline
\end{tabular}

Notes: The unit of observation is a county. Coefficients are clustered at the state level. The measure of social capital comes from Ruphasinga et al. (2014). Generalized trust (GSS) is the fraction of people in a county during the 1972-2010 period answering 1 to the following question: "Generally speaking, would you say most people can be trusted (taking the value of 1) or that you can't be too careful in dealing with people (taking the value of zero)". The dependent variables are vote shares for Donald Trump in the Republican Primaries and Presidential Elections and taken from Leip's Atlas of Presidential Elections (2016). Details about the control variables are provided in the Data description of this On-Line Appendix. ***, **, and * indicate significance at the $1 \%, 5 \%$, and $10 \%$ levels. 
Table A5 - Individual-level Analysis, CCES

\begin{tabular}{|c|c|c|c|c|c|c|}
\hline VARIABLES & $\begin{array}{c}\text { (1) } \\
\text { Voted for } \\
\text { Trump in the } \\
\text { primaries }\end{array}$ & $\begin{array}{c}\text { (2) } \\
\text { Voted for Trump } \\
\text { in general elections }\end{array}$ & $\begin{array}{c}\text { (3) } \\
\text { Prefer Trump } \\
\text { as a president }\end{array}$ & $\begin{array}{l}\text { (4) } \\
\text { Voted for Trump } \\
\text { in the primaries }\end{array}$ & $\begin{array}{l}\text { Voted for Trump in } \\
\text { general elections }\end{array}$ & $\begin{array}{c}\text { (6) } \\
\text { Prefer Trump } \\
\text { as a president }\end{array}$ \\
\hline Social capital & $\begin{array}{c}-0.022 * * * \\
(0.004)\end{array}$ & $\begin{array}{c}-0.029 * * * \\
(0.006)\end{array}$ & $\begin{array}{c}-0.024 * * * \\
(0.004)\end{array}$ & & & \\
\hline Generalized trust (GSS) & & & & $\begin{array}{l}-0.033 \\
(0.023)\end{array}$ & $\begin{array}{c}-0.089 * * * \\
(0.029)\end{array}$ & $\begin{array}{c}-0.068 * * * \\
(0.024)\end{array}$ \\
\hline Log (population density) & $\begin{array}{c}-0.018^{* * *} \\
(0.002)\end{array}$ & $\begin{array}{c}-0.028^{* * *} \\
(0.002)\end{array}$ & $\begin{array}{c}-0.025^{* * *} \\
(0.002)\end{array}$ & $\begin{array}{c}-0.022^{* * *} \\
(0.003)\end{array}$ & $\begin{array}{c}-0.023^{* * *} \\
(0.004)\end{array}$ & $\begin{array}{c}-0.024 * * * \\
(0.003)\end{array}$ \\
\hline Age & $\begin{array}{c}0.001 \\
(0.001)\end{array}$ & $\begin{array}{c}0.005^{* * *} \\
(0.001)\end{array}$ & $\begin{array}{c}0.003^{* * *} \\
(0.001)\end{array}$ & $\begin{array}{c}0.002 \\
(0.001)\end{array}$ & $\begin{array}{c}0.005^{* * *} \\
(0.001)\end{array}$ & $\begin{array}{c}0.003^{* * *} \\
(0.001)\end{array}$ \\
\hline Age squared & $\begin{array}{c}0.000 \\
(0.000)\end{array}$ & $\begin{array}{c}-0.000^{* * *} \\
(0.000)\end{array}$ & $\begin{array}{c}0.000 \\
(0.000)\end{array}$ & $\begin{array}{c}0.000 \\
(0.000)\end{array}$ & $\begin{array}{c}-0.000^{* *} \\
(0.000)\end{array}$ & $\begin{array}{c}0.000 \\
(0.000)\end{array}$ \\
\hline Female & $\begin{array}{c}-0.043^{* * *} \\
(0.005)\end{array}$ & $\begin{array}{c}-0.086^{* * *} \\
(0.005)\end{array}$ & $\begin{array}{c}-0.087^{* * *} \\
(0.004)\end{array}$ & $\begin{array}{c}-0.046^{* * *} \\
(0.006)\end{array}$ & $\begin{array}{c}-0.091^{* * *} \\
(0.006)\end{array}$ & $\begin{array}{c}-0.085^{* * *} \\
(0.005)\end{array}$ \\
\hline White & $\begin{array}{c}0.032^{* * *} \\
(0.009)\end{array}$ & $\begin{array}{c}0.066^{* * *} \\
(0.009)\end{array}$ & $\begin{array}{c}0.076^{* * *} \\
(0.008)\end{array}$ & $\begin{array}{c}0.034^{* * *} \\
(0.011)\end{array}$ & $\begin{array}{c}0.069 * * * \\
(0.011)\end{array}$ & $\begin{array}{c}0.075^{* * *} \\
(0.010)\end{array}$ \\
\hline African American & $\begin{array}{c}-0.183^{* * *} \\
(0.010)\end{array}$ & $\begin{array}{c}-0.371 * * * \\
(0.012)\end{array}$ & $\begin{array}{c}-0.258^{* * *} \\
(0.009)\end{array}$ & $\begin{array}{c}-0.160^{* * *} \\
(0.012)\end{array}$ & $\begin{array}{c}-0.326^{* * *} \\
(0.014)\end{array}$ & $\begin{array}{c}-0.223^{* * *} \\
(0.010)\end{array}$ \\
\hline Hispanic & $\begin{array}{c}-0.068^{* * *} \\
(0.013)\end{array}$ & $\begin{array}{c}-0.121 * * * \\
(0.014)\end{array}$ & $\begin{array}{c}-0.097 * * * \\
(0.009)\end{array}$ & $\begin{array}{c}-0.058^{* * *} \\
(0.015)\end{array}$ & $\begin{array}{c}-0.092^{* * *} \\
(0.017)\end{array}$ & $\begin{array}{c}-0.077 * * * \\
(0.011)\end{array}$ \\
\hline High School & $\begin{array}{c}0.008 \\
(0.020)\end{array}$ & $\begin{array}{c}0.033 \\
(0.021)\end{array}$ & $\begin{array}{c}0.028^{* *} \\
(0.012)\end{array}$ & $\begin{array}{c}0.016 \\
(0.027)\end{array}$ & $\begin{array}{c}0.050 \\
(0.032)\end{array}$ & $\begin{array}{c}0.016 \\
(0.017)\end{array}$ \\
\hline Some college & $\begin{array}{c}-0.046^{* *} \\
(0.020)\end{array}$ & $\begin{array}{l}-0.016 \\
(0.021)\end{array}$ & $\begin{array}{c}0.015 \\
(0.012)\end{array}$ & $\begin{array}{l}-0.037 \\
(0.027)\end{array}$ & $\begin{array}{l}-0.013 \\
(0.032)\end{array}$ & $\begin{array}{l}-0.003 \\
(0.017)\end{array}$ \\
\hline Two year college & $\begin{array}{c}-0.050^{* *} \\
(0.020)\end{array}$ & $\begin{array}{l}-0.023 \\
(0.021)\end{array}$ & $\begin{array}{c}0.006 \\
(0.013)\end{array}$ & $\begin{array}{l}-0.041 \\
(0.026)\end{array}$ & $\begin{array}{l}-0.020 \\
(0.032)\end{array}$ & $\begin{array}{l}-0.015 \\
(0.017)\end{array}$ \\
\hline Four year college & $\begin{array}{c}-0.105^{* * *} \\
(0.020)\end{array}$ & $\begin{array}{c}-0.097 * * * \\
(0.021)\end{array}$ & $\begin{array}{c}-0.057 * * * \\
(0.012)\end{array}$ & $\begin{array}{c}-0.085^{* * *} \\
(0.025)\end{array}$ & $\begin{array}{c}-0.085^{* * *} \\
(0.032)\end{array}$ & $\begin{array}{c}-0.066^{* * *} \\
(0.017)\end{array}$ \\
\hline Post-graduate & $\begin{array}{c}-0.145^{* * *} \\
(0.021)\end{array}$ & $\begin{array}{c}-0.178^{* * *} \\
(0.022)\end{array}$ & $\begin{array}{c}-0.120^{* * *} \\
(0.013)\end{array}$ & $\begin{array}{c}-0.122 * * * \\
(0.027)\end{array}$ & $\begin{array}{c}-0.155^{* * *} \\
(0.033)\end{array}$ & $\begin{array}{c}-0.122^{* * *} \\
(0.017)\end{array}$ \\
\hline Married & $\begin{array}{c}0.021^{* * *} \\
(0.006)\end{array}$ & $\begin{array}{c}0.044^{* * *} \\
(0.006)\end{array}$ & $\begin{array}{c}0.015^{* * *} \\
(0.005)\end{array}$ & $\begin{array}{c}0.010 \\
(0.006)\end{array}$ & $\begin{array}{c}0.023^{* * *} \\
(0.007)\end{array}$ & $\begin{array}{l}-0.007 \\
(0.006)\end{array}$ \\
\hline Divorced/separated & $\begin{array}{l}0.014^{*} \\
(0.008)\end{array}$ & $\begin{array}{c}0.027 * * * \\
(0.008)\end{array}$ & $\begin{array}{c}0.005 \\
(0.007)\end{array}$ & $\begin{array}{l}-0.006 \\
(0.009)\end{array}$ & $\begin{array}{c}0.006 \\
(0.010)\end{array}$ & $\begin{array}{c}-0.024 * * * \\
(0.009)\end{array}$ \\
\hline Widowed & $\begin{array}{c}0.018 \\
(0.013)\end{array}$ & $\begin{array}{c}0.033^{* * *} \\
(0.013)\end{array}$ & $\begin{array}{l}-0.016 \\
(0.012)\end{array}$ & $\begin{array}{c}0.010 \\
(0.016)\end{array}$ & $\begin{array}{l}-0.004 \\
(0.017)\end{array}$ & $\begin{array}{c}-0.041 * * * \\
(0.015)\end{array}$ \\
\hline Unemployed & $\begin{array}{c}0.038^{* * *} \\
(0.012)\end{array}$ & $\begin{array}{c}0.041^{* * *} \\
(0.012)\end{array}$ & $\begin{array}{l}0.015^{*} \\
(0.008)\end{array}$ & $\begin{array}{c}0.030^{* *} \\
(0.015)\end{array}$ & $\begin{array}{l}0.028^{*} \\
(0.016)\end{array}$ & $\begin{array}{c}0.021^{* *} \\
(0.010)\end{array}$ \\
\hline Out of the labor force & $\begin{array}{l}-0.008 \\
(0.006)\end{array}$ & $\begin{array}{c}-0.030^{* * *} \\
(0.006)\end{array}$ & $\begin{array}{c}-0.019 * * * \\
(0.005)\end{array}$ & $\begin{array}{c}-0.014^{*} \\
(0.008)\end{array}$ & $\begin{array}{c}-0.029 * * * \\
(0.007)\end{array}$ & $\begin{array}{c}-0.017^{* * *} \\
(0.006)\end{array}$ \\
\hline
\end{tabular}




\section{Table A5 - Individual-level Analysis, CCES (continued)}

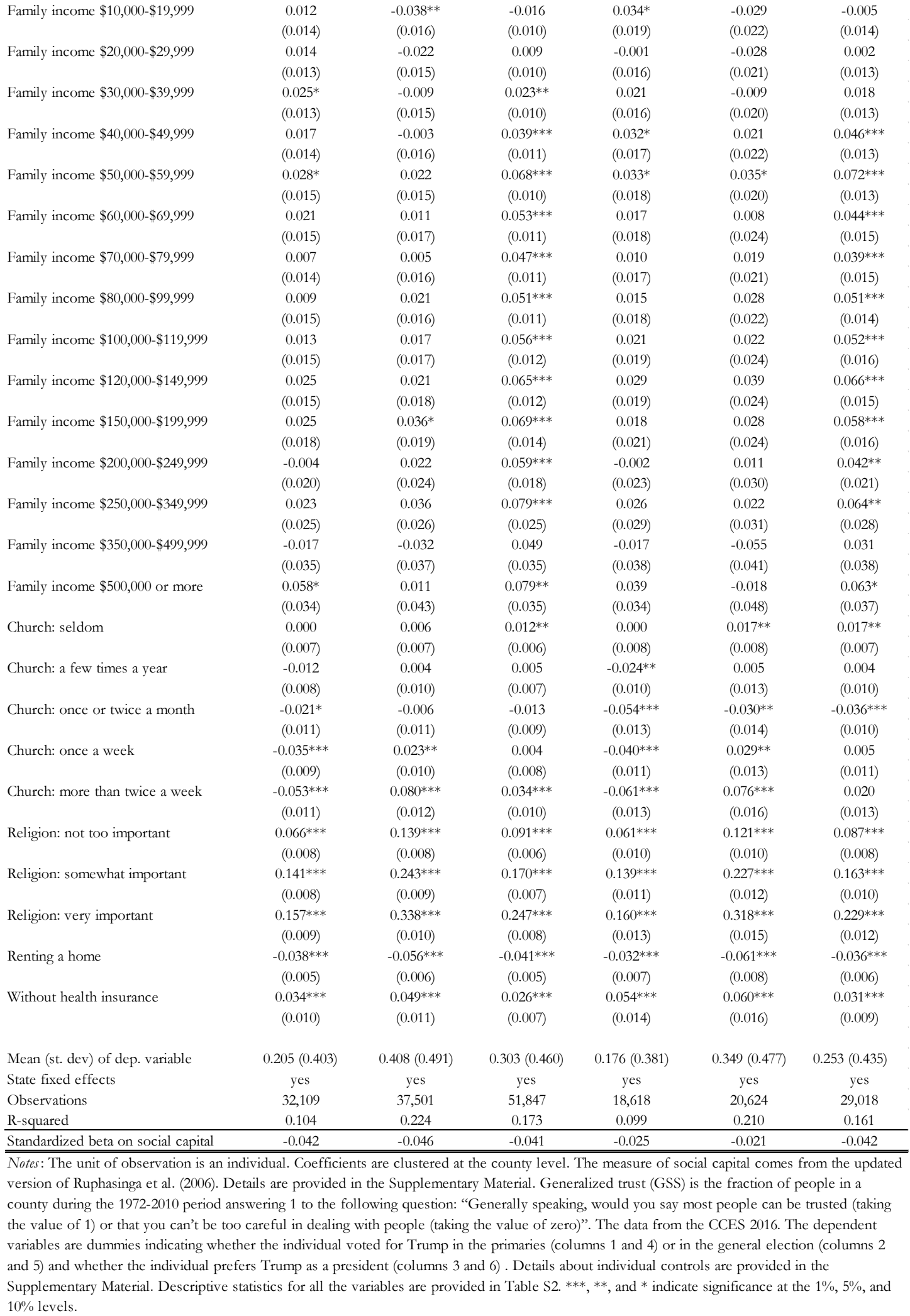


Table A6 - Individual-level Analysis, Gallup U.S. Daily Tracking

\begin{tabular}{|c|c|c|}
\hline VARIABLES & $\begin{array}{c}\text { (1) } \\
\text { Favorable opinion } \\
\text { of Trump }\end{array}$ & $\begin{array}{c}\text { (2) } \\
\text { Favorable opinion } \\
\text { of Trump } \\
\end{array}$ \\
\hline Social capital & $\begin{array}{c}-0.025^{* * *} \\
(0.003)\end{array}$ & \\
\hline Generalize trust (GSS) & & $\begin{array}{c}-0.101 * * * \\
(0.022)\end{array}$ \\
\hline Log (population density) & $\begin{array}{c}-0.025^{* * *} \\
(0.002)\end{array}$ & $\begin{array}{c}-0.026 * * * \\
(0.003)\end{array}$ \\
\hline Age & $\begin{array}{c}0.632 * * * \\
(0.042)\end{array}$ & $\begin{array}{c}0.676^{* * *} \\
(0.057)\end{array}$ \\
\hline Age squared & $\begin{array}{c}-0.421^{* * *} \\
(0.040)\end{array}$ & $\begin{array}{c}-0.440 * * * \\
(0.055)\end{array}$ \\
\hline Female & $\begin{array}{c}-0.134^{* * *} \\
(0.003)\end{array}$ & $\begin{array}{c}-0.129 * * * \\
(0.004)\end{array}$ \\
\hline White & $\begin{array}{c}0.081 * * * \\
(0.008)\end{array}$ & $\begin{array}{c}0.086^{* * *} \\
(0.010)\end{array}$ \\
\hline African American & $\begin{array}{c}-0.236^{* * *} \\
(0.010)\end{array}$ & $\begin{array}{c}-0.197^{* * *} \\
(0.011)\end{array}$ \\
\hline Hispanic & $\begin{array}{c}-0.143^{* * *} \\
(0.008)\end{array}$ & $\begin{array}{c}-0.122^{* * *} \\
(0.010)\end{array}$ \\
\hline High School & $\begin{array}{c}0.063^{* * *} \\
(0.008)\end{array}$ & $\begin{array}{c}0.089 * * * \\
(0.010)\end{array}$ \\
\hline Technical/vocational school & $\begin{array}{c}0.078^{* * *} \\
(0.011)\end{array}$ & $\begin{array}{c}0.108^{* * *} \\
(0.016)\end{array}$ \\
\hline Some College & $\begin{array}{c}0.039 * * * \\
(0.008)\end{array}$ & $\begin{array}{c}0.058^{* * *} \\
(0.011)\end{array}$ \\
\hline College graduate & $\begin{array}{c}-0.052^{* * *} \\
(0.008)\end{array}$ & $\begin{array}{c}-0.025^{* *} \\
(0.011)\end{array}$ \\
\hline Post graduate & $\begin{array}{c}-0.145^{* * *} \\
(0.009)\end{array}$ & $\begin{array}{c}-0.112^{* * *} \\
(0.012)\end{array}$ \\
\hline Married & $\begin{array}{c}0.032^{* * *} \\
(0.003)\end{array}$ & $\begin{array}{c}0.021 * * * \\
(0.004)\end{array}$ \\
\hline Divorced/separated & $\begin{array}{c}0.017 * * * \\
(0.005)\end{array}$ & $\begin{array}{c}0.015^{* *} \\
(0.006)\end{array}$ \\
\hline Widowed & $\begin{array}{c}0.007 \\
(0.006)\end{array}$ & $\begin{array}{c}0.009 \\
(0.009)\end{array}$ \\
\hline Unemployed & $\begin{array}{c}0.037^{* * *} \\
(0.008)\end{array}$ & $\begin{array}{c}0.051 * * * \\
(0.011)\end{array}$ \\
\hline Out of the labor force & $\begin{array}{c}-0.017 * * * \\
(0.003)\end{array}$ & $\begin{array}{c}-0.010^{* *} \\
(0.005)\end{array}$ \\
\hline
\end{tabular}


Table A6 - Individual-level Analysis, Gallup U.S. Daily Tracking (continued)

\begin{tabular}{|c|c|c|}
\hline Income: $\$ 720-\$ 5,999$ & $\begin{array}{c}-0.058^{* * *} \\
(0.016)\end{array}$ & $\begin{array}{c}-0.062 * * * \\
(0.021)\end{array}$ \\
\hline Income: $\$ 6,000-\$ 11,999$ & $\begin{array}{c}-0.064^{* * *} \\
(0.014)\end{array}$ & $\begin{array}{c}-0.061^{* * *} \\
(0.018)\end{array}$ \\
\hline Income: $\$ 12,000-\$ 23,999$ & $\begin{array}{c}-0.058^{* * *} \\
(0.013)\end{array}$ & $\begin{array}{c}-0.054 * * * \\
(0.016)\end{array}$ \\
\hline Income: $\$ 24,000-\$ 35,999$ & $\begin{array}{l}-0.015 \\
(0.012)\end{array}$ & $\begin{array}{l}-0.025 \\
(0.016)\end{array}$ \\
\hline Income: $\$ 36,000-\$ 47,999$ & $\begin{array}{l}-0.009 \\
(0.013)\end{array}$ & $\begin{array}{l}-0.008 \\
(0.017)\end{array}$ \\
\hline Income: $\$ 48,000-\$ 59,999$ & $\begin{array}{c}0.011 \\
(0.013)\end{array}$ & $\begin{array}{c}0.000 \\
(0.016)\end{array}$ \\
\hline Income: $\$ 60,000-\$ 89,999$ & $\begin{array}{c}0.012 \\
(0.013)\end{array}$ & $\begin{array}{c}0.008 \\
(0.016)\end{array}$ \\
\hline Income: $\$ 90,000-\$ 119,999$ & $\begin{array}{c}0.012 \\
(0.013)\end{array}$ & $\begin{array}{c}0.015 \\
(0.016)\end{array}$ \\
\hline Income: $\$ 120,000$ and over & $\begin{array}{c}0.014 \\
(0.013)\end{array}$ & $\begin{array}{c}0.012 \\
(0.016)\end{array}$ \\
\hline Church: seldom & $\begin{array}{c}0.043^{* * *} \\
(0.004)\end{array}$ & $\begin{array}{c}0.045^{* * *} \\
(0.004)\end{array}$ \\
\hline Church: about once a month & $\begin{array}{c}0.044 * * * \\
(0.005)\end{array}$ & $\begin{array}{c}0.048^{* * *} \\
(0.006)\end{array}$ \\
\hline Church: almost every week & $\begin{array}{c}0.024 * * * \\
(0.006)\end{array}$ & $\begin{array}{c}0.027 * * * \\
(0.007)\end{array}$ \\
\hline Church: every week & $\begin{array}{c}0.041 * * * \\
(0.005)\end{array}$ & $\begin{array}{c}0.051 * * * \\
(0.006)\end{array}$ \\
\hline Religion important & $\begin{array}{c}0.147^{* * *} \\
(0.004)\end{array}$ & $\begin{array}{c}0.137 * * * \\
(0.005)\end{array}$ \\
\hline Mean (st. dev.) of dep. variable & $0.369(0.482)$ & $0.311(0.463)$ \\
\hline State fixed effects & yes & yes \\
\hline Year fixed effects & yes & yes \\
\hline Observations & 114,186 & 58,015 \\
\hline R-squared & 0.156 & 0.150 \\
\hline Standardized beta on social capital & -0.042 & -0.03 \\
\hline
\end{tabular}

Notes: The unit of observation is an individual. Coefficients are clustered at the county level. The measure of social capital comes from the updated version of Ruphasinga et al. (2006). Details are provided in the Supplementary Material. Generalized trust (GSS) is the fraction of people in a county during the 1972-2010 period answering 1 to the following question: "Generally speaking, would you say most people can be trusted (taking the value of 1) or that you can't be too careful in dealing with people (taking the value of zero)". The data are from Gallup Daily 2016-2017. The dependent variable is a dummy indicating whether the individual has a favorable opinion of Trump . Details about individual controls are provided in the Supplementary Material. Descriptive statistics for all the variables are provided in Table S3. ***, **, and $*$ indicate significance at the $1 \%, 5 \%$, and $10 \%$ levels. 


\section{TableA7 - Individual-level Analysis, Gallup U.S. Daily Tracking, alternative coding of favorable opinions of Trump}

\begin{tabular}{|c|c|c|}
\hline VARIABLES & $\begin{array}{c}\text { (1) } \\
\text { Favorable opinion } \\
\text { of Trump } \\
\end{array}$ & $\begin{array}{c}\text { (2) } \\
\text { Favorable opinion } \\
\text { of Trump } \\
\end{array}$ \\
\hline Social capital & $\begin{array}{c}-0.024 * * * \\
(0.003)\end{array}$ & \\
\hline Generalize trust (GSS) & & $\begin{array}{c}-0.095^{* * *} \\
(0.021)\end{array}$ \\
\hline Log (population density) & $\begin{array}{c}-0.024 * * * \\
(0.001)\end{array}$ & $\begin{array}{c}-0.025^{* * *} \\
(0.003)\end{array}$ \\
\hline Age & $\begin{array}{c}0.642^{* * *} \\
(0.040)\end{array}$ & $\begin{array}{c}0.671 * * * \\
(0.054)\end{array}$ \\
\hline Age squared & $\begin{array}{c}-0.425^{* * *} \\
(0.038)\end{array}$ & $\begin{array}{c}-0.433^{* * *} \\
(0.052)\end{array}$ \\
\hline Female & $\begin{array}{c}-0.131 * * * \\
(0.003)\end{array}$ & $\begin{array}{c}-0.126 * * * \\
(0.004)\end{array}$ \\
\hline White & $\begin{array}{c}0.087^{* * *} \\
(0.007)\end{array}$ & $\begin{array}{c}0.093^{* * *} \\
(0.010)\end{array}$ \\
\hline African American & $\begin{array}{c}-0.220 * * * \\
(0.009)\end{array}$ & $\begin{array}{c}-0.183 * * * \\
(0.010)\end{array}$ \\
\hline Hispanic & $\begin{array}{c}-0.130 * * * \\
(0.008)\end{array}$ & $\begin{array}{c}-0.110^{* * *} \\
(0.009)\end{array}$ \\
\hline High School & $\begin{array}{c}0.070 * * * \\
(0.007)\end{array}$ & $\begin{array}{c}0.093 * * * \\
(0.009)\end{array}$ \\
\hline Technical/vocational school & $\begin{array}{c}0.082^{* * *} \\
(0.010)\end{array}$ & $\begin{array}{c}0.110^{* * *} \\
(0.015)\end{array}$ \\
\hline Some College & $\begin{array}{c}0.050 * * * \\
(0.007)\end{array}$ & $\begin{array}{c}0.065^{* * *} \\
(0.010)\end{array}$ \\
\hline College graduate & $\begin{array}{c}-0.037 * * * \\
(0.007)\end{array}$ & $\begin{array}{l}-0.014 \\
(0.010)\end{array}$ \\
\hline Post graduate & $\begin{array}{c}-0.128^{* * *} \\
(0.008)\end{array}$ & $\begin{array}{c}-0.099 * * * \\
(0.011)\end{array}$ \\
\hline Married & $\begin{array}{c}0.030 * * * \\
(0.003)\end{array}$ & $\begin{array}{c}0.019 * * * \\
(0.004)\end{array}$ \\
\hline Divorced/separated & $\begin{array}{c}0.016^{* * *} \\
(0.005)\end{array}$ & $\begin{array}{c}0.013^{* *} \\
(0.006)\end{array}$ \\
\hline Widowed & $\begin{array}{c}0.005 \\
(0.006)\end{array}$ & $\begin{array}{c}0.008 \\
(0.009)\end{array}$ \\
\hline Unemployed & $\begin{array}{c}0.038^{* * *} \\
(0.008)\end{array}$ & $\begin{array}{c}0.049 * * * \\
(0.010)\end{array}$ \\
\hline Out of the labor force & $\begin{array}{c}-0.015^{* * *} \\
(0.003)\end{array}$ & $\begin{array}{c}-0.009 * * \\
(0.004)\end{array}$ \\
\hline
\end{tabular}


Table A7 - Individual-level Analysis, Gallup U.S. Daily Tracking, alternative coding of favorable opinions of Trump (continued)

\begin{tabular}{|c|c|c|}
\hline Income: $\$ 720-\$ 5,999$ & $\begin{array}{c}-0.046^{* * *} \\
(0.015)\end{array}$ & $\begin{array}{c}-0.045^{* *} \\
(0.019)\end{array}$ \\
\hline Income: $\$ 6,000-\$ 11,999$ & $\begin{array}{c}-0.055^{* * *} \\
(0.013)\end{array}$ & $\begin{array}{c}-0.048^{* * *} \\
(0.016)\end{array}$ \\
\hline Income: $\$ 12,000-\$ 23,999$ & $\begin{array}{c}-0.043^{* * *} \\
(0.012)\end{array}$ & $\begin{array}{c}-0.038^{* *} \\
(0.015)\end{array}$ \\
\hline Income: $\$ 24,000-\$ 35,999$ & $\begin{array}{l}-0.000 \\
(0.012)\end{array}$ & $\begin{array}{l}-0.007 \\
(0.015)\end{array}$ \\
\hline Income: $\$ 36,000-\$ 47,999$ & $\begin{array}{c}0.007 \\
(0.013)\end{array}$ & $\begin{array}{c}0.010 \\
(0.016)\end{array}$ \\
\hline Income: $\$ 48,000-\$ 59,999$ & $\begin{array}{c}0.028^{* *} \\
(0.012)\end{array}$ & $\begin{array}{c}0.019 \\
(0.015)\end{array}$ \\
\hline Income: $\$ 60,000-\$ 89,999$ & $\begin{array}{c}0.030^{* *} \\
(0.012)\end{array}$ & $\begin{array}{l}0.028^{*} \\
(0.014)\end{array}$ \\
\hline Income: $\$ 90,000-\$ 119,999$ & $\begin{array}{c}0.030^{* *} \\
(0.012)\end{array}$ & $\begin{array}{c}0.034^{* *} \\
(0.015)\end{array}$ \\
\hline Income: $\$ 120,000$ and over & $\begin{array}{c}0.034^{* * *} \\
(0.012)\end{array}$ & $\begin{array}{c}0.034^{* *} \\
(0.015)\end{array}$ \\
\hline Church: seldom & $\begin{array}{c}0.042^{* * *} \\
(0.004)\end{array}$ & $\begin{array}{c}0.044 * * * \\
(0.004)\end{array}$ \\
\hline Church: about once a month & $\begin{array}{c}0.044^{* * *} \\
(0.005)\end{array}$ & $\begin{array}{c}0.047^{* * *} \\
(0.006)\end{array}$ \\
\hline Church: almost every week & $\begin{array}{c}0.022^{* * *} \\
(0.005)\end{array}$ & $\begin{array}{c}0.026^{* * *} \\
(0.007)\end{array}$ \\
\hline Church: every week & $\begin{array}{c}0.037^{* * *} \\
(0.004)\end{array}$ & $\begin{array}{c}0.046^{* * *} \\
(0.006)\end{array}$ \\
\hline Religion important & $\begin{array}{c}0.141^{* * *} \\
(0.004)\end{array}$ & $\begin{array}{c}0.132^{* * *} \\
(0.005)\end{array}$ \\
\hline Mean (st. dev.) of dep. variable & $0.355(0.479)$ & $0.300(0.458)$ \\
\hline State fixed effects & yes & yes \\
\hline Year fixed effects & yes & yes \\
\hline Observations & 118,460 & 60,068 \\
\hline R-squared & 0.149 & 0.144 \\
\hline Standardized beta on social capital & -0.04 & -0.029 \\
\hline \multicolumn{3}{|c|}{$\begin{array}{l}\text { Notes: The unit of observation is an individual. Coefficients are clustered at the } \\
\text { county level. The measure of social capital comes from the updated version of } \\
\text { Ruphasinga et al. (2006). Details are provided in the Supplementary Material. } \\
\text { Generalized trust (GSS) is the fraction of people in a county during the } 1972- \\
2010 \text { period answering } 1 \text { to the following question: "Generally speaking, would } \\
\text { you say most people can be trusted (taking the value of } 1 \text { ) or that you can't be } \\
\text { too careful in dealing with people (taking the value of zero)". The data are from } \\
\text { Gallup Daily } 2016-2017 \text {. The dependent variable is a dummy indicating whether } \\
\text { the individual has a favorable opinion of Trump. The excluded groups are } \\
\text { people with an unfavorable opinion, people who have heard of him but do not } \\
\text { have an opinion, and people who do not have heard of him. Details about } \\
\text { individual controls are provided in the Supplementary Material. Descriptive } \\
\text { statistics for all the variables are provided in Table A3. ***, **, and * indicate } \\
\text { significance at the } 1 \%, 5 \% \text {, and } 10 \% \text { levels. }\end{array}$} \\
\hline
\end{tabular}


Table A8 - Individual-level Analysis, robustness to the inclusion of additional county controls

\begin{tabular}{|c|c|c|c|c|c|c|c|c|}
\hline VARIABLES & $\begin{array}{c}\text { (1) } \\
\text { Voted for } \\
\text { Trump in the } \\
\text { primaries }\end{array}$ & $\begin{array}{c}\text { (2) } \\
\text { Voted for Trump } \\
\text { in general election }\end{array}$ & $\begin{array}{c}\text { (3) } \\
\text { Prefer Trump } \\
\text { as a president }\end{array}$ & $\begin{array}{c}\text { (4) } \\
\text { Favorable opinion } \\
\text { of Trump }\end{array}$ & $\begin{array}{l}\text { Voted for Trump } \\
\text { in the primaries }\end{array}$ & $\begin{array}{l}\text { Voted for Trump in } \\
\text { general election }\end{array}$ & $\begin{array}{l}\text { (7) } \\
\text { Prefer Trump } \\
\text { as a president }\end{array}$ & $\begin{array}{l}\text { Favorable opinion } \\
\text { of Trump }\end{array}$ \\
\hline Social capital & $\begin{array}{c}-0.016 * * * \\
(0.005)\end{array}$ & $\begin{array}{c}-0.017 * * * \\
(0.006)\end{array}$ & $\begin{array}{c}-0.017 * * * \\
(0.005)\end{array}$ & $\begin{array}{c}-0.024 * * * \\
(0.004)\end{array}$ & & & & \\
\hline Generalized trust (GSS) & & & & & $\begin{array}{l}-0.027 \\
(0.024)\end{array}$ & $\begin{array}{r}-0.046^{*} \\
(0.028)\end{array}$ & $\begin{array}{c}-0.058 * * \\
(0.025)\end{array}$ & $\begin{array}{c}-0.080 * * * \\
(0.022)\end{array}$ \\
\hline Mean (st. dev) of dep. variable & $0.211(0.408)$ & $0.418(0.493)$ & $0.316(0.465)$ & $0.368(0.482)$ & $0.182(0.386)$ & $0.359(0.480)$ & $0.265(0.442)$ & $0.312(0.463)$ \\
\hline Individual controls & yes & yes & yes & yes & yes & yes & yes & yes \\
\hline Year fixed effects & no & no & no & yes & no & no & no & yes \\
\hline State fixed effects & yes & yes & yes & yes & yes & yes & yes & yes \\
\hline Observations & 29,242 & 34,420 & 46,735 & 111,827 & 16,575 & 18,505 & 25,458 & 57,343 \\
\hline R-squared & 0.109 & 0.231 & 0.177 & 0.158 & 0.106 & 0.226 & 0.169 & 0.153 \\
\hline Standardized beta on social capital & -0.028 & -0.026 & -0.027 & $\begin{array}{l}-0.039 \\
\end{array}$ & -0.01 & -0.013 & -0.018 & $\begin{array}{l}-0.024 \\
\end{array}$ \\
\hline \multicolumn{9}{|c|}{$\begin{array}{l}\text { Notes: The unit of observation is an individual. Coefficients are clustered at the county level. The measure of social capital comes from the updated version of Ruphasinga et al. (2006). Details are provided } \\
\text { in the Supplementary Material. Generalized trust (GSS) is the fraction of people in a county during the 1972-2010 period answering } 1 \text { to the following question: "Generally speaking, would you say most } \\
\text { people can be trusted (taking the value of 1) or that you can't be too careful in dealing with people (taking the value of zero)". Data for columns } 1-3 \text { and 5-7 come from the CCES } 2016 \text {, whereas for column } \\
4 \text { and } 8 \text { are obtained by Gallup Daily 2016-2017. The dependent variables are dummies indicating whether the individual voted for Trump in the primaries (column 1) or in the general election (column } 2 \text { ), } \\
\text { whether the individual prefers Trump as a president (column 3) and whether he/she has a favourable opinion of Trump (column 4). Individual controls include age, gender, race, income, education, labor } \\
\text { force and marital status, how often the person goes to church, how important religion is in her/his life, a measure of home ownership and whether the person has health insurance. County level controls } \\
\text { include the percentage of the population aged } 25 \text { and above with high school education or more (2009-2013), median household income (2009-2013), the percentage of Whites, African Americans and } \\
\text { Hispanics (2014), unemployment rate (2016) and the change in manufacturing employment for the 2000-2015 period. Details about the control variables are provided in the Supplementary Material. Tables } \\
\text { A5 and A6 show the coefficients for all the individual controls. Descriptive statistics for all the variables are provided in Tables A2 and A3. ***, **, and *indicate significance at the } 1 \%, 5 \% \text {, and } 10 \% \text { levels. }\end{array}$} \\
\hline
\end{tabular}




\section{Appendix References}

Leip, D., 2016, “Atlas of U.S. Presidential Elections”, https://uselectionatlas.org/

Rupasingha, A., S. Goetz and D. Freshwater, 2006, "The production of social capital in US counties”, The Journal of Socio-Economics, 35, 83-101. 